\title{
Litigating in the Time of Coronavirus: Mental Health Tribunals' Response to COVID-19
}

\author{
Ruby Dhand \\ Anita Szigeti \\ Maya Kotob \\ Michael Kennedy \\ Rebecca Ye*
}

\begin{abstract}
People with mental health and addiction issues are disproportionately affected by COVID-19 given the elevated risk of contracting COVID-19 within psychiatric facilities. The impact of the pandemic on this extraordinarily vulnerable population includes the potential for large outbreaks and multiple deaths. There is also the increased risk of serious psychological harm, exacerbating preexisting mental health and substance use issues and in turn elevating their risk to themselves and/or others. In Part I of this paper, we analyze the procedural barriers to access to justice that arose as a result of the initial responses to COVID-19 by the Consent and Capacity Board [CCB] and the Ontario Review Board [ORB]. In Part V, we include a brief report on how appeals taken from both tribunals have been handled throughout COVID-19 to date. In Part VI, we analyze the discretionary and systemic barriers experienced by people with mental health and addiction issues appearing before the CCB and ORB during COVID-19. We critique recent mental health law cases during COVID-19 where deprivations of liberty interests and substantive equality have occurred, and access to justice for people with mental health and addictions issues has been denied, suspended or impaired. Through a legal analysis of how the pandemic has impacted this vulnerable community of litigants, we hope this research will result in further advocacy and education to prevent outbreaks and death, improve health care practices, and increase access to justice.
\end{abstract}

Les personnes qui ont des problèmes de santé mentale et de toxicomanie sont touchées de façon disproportionnée par la COVID-19, vu le risque élevé de contracter la COVID-19 dans les établissements psychiatriques. Les répercussions de la pandémie sur cette population extrêmement vulnérable comprennent la possibilité d'éclosions importantes et de décès multiples. Il y a également le risque accru de préjudice psychologique grave, qui exacerbe les problèmes de santé mentale et de toxicomanie préexistants et qui augmente les risques que les personnes souffrant de ces problèmes posent pour elles-mêmes ou pour d'autres personnes. Dans la partie I du présent document, nous analysons les obstacles procéduraux à l'accès à la justice qui sont apparus à la suite des réponses initiales à la COVID-19 par la Commission du consentement et de la capacité [CCC] et la Commission ontarienne d'examen [COE]. Dans la partie V, nous présentons un bref rapport sur la façon dont les appels interjetés à l'encontre des décisions des deux tribunaux ont jusqu'à présent été traités pendant la pandémie de COVID-19. Dans la partie VI, nous analysons les obstacles discrétionnaires et systémiques auxquels se heurtent les personnes ayant des problèmes de santé mentale et de toxicomanie qui comparaissent devant la CCC et la COE pendant la pandémie de COVID-19. Nous critiquons de récentes affaires en matière de santé mentale qui ont été instruites pendant la pandémie de COVID-19, dans lesquelles des privations de liberté et

* Ruby Dhand, Associate Professor, Faculty of Law, Thompson Rivers University, B.A., M.A., LL.B., LL.M., Ph.D (Osgoode); Anita Szigeti, Principal Lawyer, Anita Szigeti Advocates, LL.B (Toronto); Maya Kotob, Associate Lawyer, Anita Szigeti Advocates, LL.B., LL.M (Manchester); Michael Kennedy, JD candidate; Rebecca Ye, JD candidate. This paper's research is current as of November 1, 2020. 
des dénis d'égalité réelle ont eu lieu et où l'accès à la justice pour les personnes ayant des problèmes de santé mentale et de toxicomanie a été refusé, suspendu ou compromis. Grâce à une analyse juridique des effets de la pandémie sur la communauté vulnérable de plaideurs qui nous intéresse, nous espérons que nos recherches mèneront à d'autres activités de sensibilisation et d'éducation visant à prévenir les éclosions et les décès, à améliorer les pratiques de soins de santé et à élargir l'accès à la justice.

People with mental health and addictions issues experience significant barriers to accessing justice. This is equally the case for individuals detained pursuant to provincial health legislation (civil commitment) and those who become entangled in criminal justice consequent to mental disorder (forensic psychiatric detainees). ${ }^{1}$ Existing barriers to access to justice for persons with mental health issues in civil and criminal justice systems are heightened by the COVID-19 pandemic. ${ }^{2}$ People with mental health and addictions issues often experience procedural, discretionary and systemic barriers in gaining access to the various mental health tribunals and during adjudication of their cases. ${ }^{3}$ Whenever individuals require a mental health related tribunal hearing, their liberty or autonomy is at stake. All mental health law litigation is about Charter ${ }^{4}$ protected rights to life, liberty, security of the person and/or the right to self-determination and bodily integrity. ${ }^{5}$

1 Tess C Sheldon, Karen R Spector \& Mercedes Perez, "Re-Centering Equality: The Interplay Between Sections 7 and 15 of the Charter in Challenges to Psychiatric Detention" (2016) 35:2 NJCL 193 at 203-04; Ruby Dhand, "Access to Justice for Ethno-Racial Psychiatric Consumer/Survivors in Ontario" (2011) 29 Windsor YB Access Just 127 [Dhand, "Access to Justice"]; Sophie Nunnelley, "Involuntary Hospitalization and Treatment: Themes and Controversies" in Jennifer A Chandler \& Colleen M Flood, eds, Law \& Mind: Canadian Mental Health Law and Policy (Markham, ON: LexisNexis Canada, 2016) 113 at 113-38; Ruby Dhand \& Kerri Joffe, "Involuntary Detention and Involuntary Detention and Involuntary Treatment Through the Lens of Sections 7 and 15 of the Canadian Charter of Rights and Freedoms," (2020) 42:3 Man LJ 78; PS v Ontario 2014 ONCA 900 [PS]; Michael L Perlin and Eva Szeli, "Mental Health Law and Human Rights: Evolution and Contemporary Challenges" (2008) New York Law School Legal Studies Research Paper No 07/08-28.

2 Kendra Milne, "Who’s Left Out? COVID-19 \& Psychiatric Detainees" (21 April 2020), online: Policynote $<$ https://www.policynote.ca/psychiatric-detainees/>; Sheila Wildeman, Tess Sheldon \& Karen Spector, "Viruses Feed on Exclusion: Psychiatric Detention and the Need for Preventative Detention" (12 April 2020), online: Ricochet $<$ https://ricochet.media/en/3038/viruses-feed-on-exclusion-psychiatric-detention-and-the- need-for- preventativedeinstitutionalization>; Bazelon Centre for Mental Health Law, "During the Pandemic, States and Localities Must Decrease the Number of Individuals In Psychiatric Hospitals, By Reducing Admissions and Accelerating Discharges", online: < http://www.bazelon.org/wp-content/uploads/2020/04/4-15-20-BC-psych-hospitals-statement-FINAL.pdf $>$; Min Joo Kim, "Coronavirus in South Korean psychiatric wards became a 'medical disaster' when coronavirus hit", The Washington Post (29 February 2020), online: <https://www.washingtonpost.com/world/asia_pacific/how-a-southkorean-psychiatric- ward-became-a-medical-disaster-when-coronavirus-hit/2020/02/29/fe8f6e40-5897-11 ea- 8efd0f904bdd8057_story.html>; Michael Liebrenz et al, "Caring for persons in detention suffering with mental illness during the Covid-19 outbreak" (2020) 1 Forensic Science International: Mind and Law 1 at 1-2; Susan McMahon, "Pandemic as Opportunity for Competence Restoration Decarceration" (October 21, 2020), Ariz St LJ Online, online: SSRN $<$ https://ssrn.com/abstract $=3716250>$.

3 See sources at supra note 1

4 Canadian Charter of Rights and Freedoms, Part I of the Constitution Act, 1982, being Schedule B to the Canada Act 1982 (UK), 1982, c 11 [Charter].

$5 \quad$ Fleming v Reid, (1991), 4 OR (3d) 74, 82 DLR (4th) 298 (ONCA) [Fleming]; Starson v Swayze 2003 SCC 32 [Starson]. Starson in the SCC is an exceptionally important recognition of bodily integrity and autonomy as protected rights in the context of treatment decision making and capacity to consent to proposed treatment. However, it is not a constitutional law case. See also, D’Arcy Hiltz, Anita Szigeti \& Ruby Dhand, Halsbury's Laws of Canada Mental Health Law, 3rd ed (Toronto: Lexis Nexis, 2019) at 20 and see sources at supra note 1; D'Arcy Hiltz \& Anita Szigeti, A Guide to Consent and Capacity Law in Ontario, 2021 Edition (Markham: Lexis Nexis Canada, 2020) at 1. 
Canadian mental health jurisprudence reflects the paternalistic heritage of coercion and control through archaic parens patriae powers, "founded on necessity, namely the [state's] need to act for the protection of those who cannot care for themselves." Instead of removing societal barriers to discrimination, provincial governments have focused on involuntary hospital admission and forced psychiatric treatment in an attempt to promote "protection," "recovery," and "rehabilitation." Canadian Courts have predominantly interpreted mental health legislation as "protective" and "remedial," while Charter protected rights to liberty, ${ }^{9}$ autonomy in determining what is done with one's own body, ${ }^{10}$ and substantive equality $^{11}$ are less likely to be rigorously enforced. The voices of people with mental health issues are often silenced. They continue to be denied meaningful access to justice in the absence of sufficient procedural safeguards or the refusal to adhere strictly to such safeguards where they exist in law. Given the coercive nature of Canadian mental health laws, people with mental health and addictions issues experience violations of sections 7 and 15 Charter rights, as well as breaches of international human rights treaties. $^{12}$

The COVID-19 pandemic has a disproportionate impact and adverse effect on people with mental health and addictions issues detained in civil and forensic psychiatric facilities. ${ }^{13}$ Many psychiatric detainees have contracted COVID-19 within the institutions. ${ }^{14}$ Some died. ${ }^{15}$ Psychiatric facilities are

$6 E(M r s) v E v e$, [1986] 2 SCR 388 at 51, 31 DLR (4th) 1. The rationale was to be used for one's "best interest" [E (Mrs)].

$7 \quad$ Ontario (Public Trustee) v Brika 1987, 61 OR (2d) 58 at 5, 1987 CarswellOnt 1013 (ONSC). See the following at supra note 1, Sheldon, Spector \& Perez; Dhand \& Joffe; Nunnelley; PS.

$8 \quad$ Ibid.

$9 \quad$ Fleming, supra note 5. See also, sources at supra note 1. Although in a series of Supreme Court of Canada Judgments in the context of NCR accused and their rights in the forensic system, liberty interests of the person with mental disorder are recognized as a "major preoccupation" of the tribunal. See Winko v British Columbia (Forensic Psychiatric Institute), 1999 CanLII 694 (SCC), [1999] 2 SCR 625 [Winko]; Pinet v St. Thomas Psychiatric Hospital, [2004] 1 SCR 528, 2004 SCC 21 [Pinet]; Penetanguishene Mental Health Centre v Ontario (Attorney General), [2004] 1 SCR 498, 2004 SCC 20 [Tulikorpi].

10 Starson, supra note 5; See also, see sources at supra note 1.

11 Ontario (Attorney General) v G; and Gv Ontario (Attorney General) did recognize the Charter section 15 arguments made by NCR accused who have received absolute discharges from the Review Board, to the right to seek exempted from Sex Offender Registries, G v Ontario (Attorney General), 2019 ONCA 264 at paras 127, 134; Ontario (Attorney General) $v$ G, 2020 SCC 38.

12 Convention on the Rights of Persons with Disabilities, A Res 61/106, UNGAOR, 61st Sess, Supp No 49 (2006) 2 at 4, art 1, online (pdf): <treaties.un.org/doc/Publication/CTC/Ch_IV_15.pdf> [perma.cc/22JM-C6JK] [CRPD]. Michael L

Perlin, "Chimes of Freedom: International Human Rights and Institutional Mental Disability Law" (2002) 21:3 NYL Sch J Intl \& Comparative L 423 at 427. Disability advocates argue that mental health legislation violates multiple sections of the Convention and areas of fundamental human rights as explained in Piers Gooding, "Supported Decision-Making: A Rights-Based Disability Concept and Its Implications for Mental Health Law” (2013) 20:3 Psychiatry, Psychology \& L 431 at 440.

13 See sources at supra note 2.

14 As of October 30, 2020, at the Centre for Addiction and Mental Health (CAMH) in Toronto, Ontario (Canada's largest psychiatric facility), there have been 2 deaths of inpatients with COVID-19, 48 patients who received a positive COVID19 diagnosis and 23 patients with a resolved positive COVID-19 diagnosis. There have been only 3 patients with COVID-19 who have been discharged from CAMH. Centre for Addiction and Mental Health, "COVID-19 Updates" (30 October 2020), online: <https://www.camh.ca/en/camh-news-and-stories/novel-coronavirus-update> [CAMH, "COVID 19 Updates"]; See also, sources at supra note 2.

15 Liebrenz et al argues, in relation to COVID-19, "it is also known that infections which are transmitted human to human via droplet or close contact spread particularly well in confined spaces. Since transfer options for further treatment are more difficult (especially in detention facilities) preventive measures are strongly emphasized, particularly in the case of viral droplet infections... If such options are not available, prisons and other closed facilities, like asylum centers, 
"congregate facilities"16 where members of this vulnerable community live in confined spaces with high transmission risks of contracting COVID-19. In this regard, they are akin to long-term care facilities and prisons. ${ }^{17}$ It would be a mistake to think of a psychiatric 'hospital' as a medical facility that is able to provide emergency medical care in the event of complications from the corononavirus. ${ }^{18}$ There are thousands of people with mental health and addictions issues, who are involuntarily detained in civil and forensic psychiatric facilities pursuant to provincial mental health legislation and the Criminal Code of Canada, respectively. ${ }^{19}$ Psychiatric detainees are at a heightened risk of contracting COVID-19 within institutional settings for a host of reasons including the following: (1) pre-existing medical conditions and vulnerabilities, ${ }^{20}(2)$ consent /capacity issues ${ }^{21}$ and (3) the lack of resources and community-based care options. ${ }^{22}$ It is generally not possible for individuals detained in psychiatric facilities to practise physical distancing due to the crowded nature of these facilities. Those detained involuntarily are unable to leave the facility or choose to receive care in the community or remotely / electronically, rather than being seen in close contact and in person by all staff inside the institution round the clock.

The disproportionately adverse impact of COVID-19 on this extraordinarily vulnerable population includes the potential for large outbreaks and multiple deaths. There is also the additional elevated risk of the individual clients suffering serious psychological harm, exacerbating pre-existing mental health and substance use issues and in turn elevating their risk to themselves and/or others. ${ }^{23}$

shelters, and closed psychiatric hospitals, pose a risk for the rapid spread of such diseases”, Liebrenz et al, supra note 2 at 2 .

16 Blake (Re), [2020] ORBD No 51 at para 39 [Blake] in which case an affidavit of Dr. Aaron Orkin, dated April 7, 2020, at para 23 was filed; see also, affidavit of Dr. Aaron Orkin, date May 20, 2020, at para 29, 56. See also sources supra note 2 .

17 See sources at supra note 2 and also, the volume of bail review jurisprudence, for the proposition that congregate settings like jails / prisons must be depopulated to reduce COVID-19 transmission risks including: $R v$ Rajan 2020 ONSC 2118; $R v$ $C J$ [27 March 2020], Ont SCJ; $R$ v. Cahill 2020 ONSC 2171; $R v$ Cain, 2020 ONSC 2018; $R v$ JS, 2020 ONSC $1710[J S] ; R v$ King, 2020 ONSC 1935; $R v$ TL, 2020 ONSC 1885; $R v$ TK 2020 ONSC 1935; $R v$ Williams, 2020 ONSC 2237.

18 See CAMH's COVID-19 protocol, which includes transfers to a general hospital for medical care needed to address coronavirus complications. CAMH, "COVID 19 Updates", supra note 14.

19 Criminal Code, RSC 1985, c C-46, s 672.62; Hiltz, Szigeti \& Dhand, supra note 5 at 1 and 103; Michael Davies et al, $A$ Guide to Mental Disorder Law in Canadian Criminal Justice (Markham: Lexis Nexis Canada, 2020); Nunnelley, supra note 1 .

20 Many patients are diabetic and have other cardiovascular issues related to long-term treatment with some anti-psychotic medications. Diabetes is recognized as contributing to elevated risk of serious COVID-19 disease and death. Centre for Disease Control and Prevention, "COVID-19: People of Any Age with Underlying Medical Conditions," online: $<$ https://www.cdc.gov/coronavirus/2019-ncov/need-extra-precautions/people-with-medical-conditions.html\#diabetes>.

21 For so called 'dual diagnosis' patients, there may be issues of cognitive impairment or learning disability that would / could compromise a person's ability to employ public health measures designed to reduce the risk of transmission of Covid-19 within or outside the institution, albeit that it should never be presumed that a person with a psychiatric diagnostic label has impaired cognition or intellectual functioning or learning abilities. Centre for Addiction and Mental Health, "Dual Diagnosis," online: $<$ https://www.camh.ca/en/health-info/mental-illness-and-addiction-index/dualdiagnosis $>$.

22 See sources at supra note 2.

23 Ibid. For an analysis of the emergency response measures to the COVID-19 pandemic, see Canadian Civil Liberties Association, "COVID-19 Live Liberty Updates: Emergency Measures Across Canada in Response to COVID-19 Crisis," online: <https://ccla.org/coronavirus-update-emergency-measures-by-province/>; PBP Lawyers, "COVID-19, Quarantine and Government Emergency Powers," online: $\leq$ http://pbplawyers.com/2020/03/21/covid-19-quarantine-andgovernment-emergency-powers/>. 
Given the elevated risk of contracting COVID-19 within congregate settings, which include psychiatric facilities, depopulating these hospitals is a measure that ought to have been employed to reduce public health risks for the inpatient / client / psychiatric detainee, as well as for staff who come to work each day on these units at the institutions. Depopulation efforts require appropriate access to justice and broad availability and strict enforcement of legal / procedural safeguards. Without such broad and flexible access to justice and to procedural due process before mental health administrative tribunals, all depopulation efforts were doomed to fail. These tribunals needed to be open to reframing their preCOVID-19 perceptions of the psychiatric hospital as true 'asylum', a safe-haven to protect the individual from him / herself and the public from a potentially dangerous "mentally ill offender", to make room for conceiving of the psychiatric institution as a source of serious public health risk, if sufficient numbers of the inpatient detainees are not released, and released quickly.

This paper covers procedural and substantive responses of mental health tribunals in Ontario to COVID-19 and concludes that significant barriers to access to justice have been consistently noted, leading to elevated risk for psychiatric inpatients, both in terms of contracting the disease and potential for severe outcomes, including death.

We argue that these access to justice issues also result in a host of troubling collateral consequences and outcomes for psychiatric patient / clients including: restrictions of liberty, lack of procedural safeguards and due process in the adjudication context, unfair changes to mental health laws and policies, increased use of "solitary confinement, seclusion and indefinite lockdowns of psychiatric facilities" 24 without access to essential community and social supports. ${ }^{25} \mathrm{We}$ also recognize the intersectional nature of discrimination and inequities experienced by people with mental health and addictions during COVID19. We remain mindful that the same client population is often adversely affected by negative social determinants of health such as poverty, lack of social supports, increased criminalization, systemic discrimination and racism. ${ }^{26}$

Procedural fairness and equal protection under the law are fundamental to access to justice. ${ }^{27}$ In the mental health adjudication context, access to justice for persons with serious mental health issues has been compromised during COVID-19. While there have been definite side-benefits to the necessary responses mental health tribunals have had to make to accommodate the mandated remote operations during COVID, in some respects there has been an evident suspension of due process and procedural fairness. In this paper we cover all developments, both positive and negative, with a view to looking for recommendations to improve mental health adjudication going forward during COVID and beyond.

Our analysis draws from multiple academic sources, including our own experience as front-line lawyers, academics and advocates specializing in mental health law and appearing before all mental health tribunals in Ontario. We examine the extent to which mental health tribunals in Ontario have used the "social control model" 28 during the COVID-19 pandemic in their adjudicative processes. As articulated by Professor Isabel Grant, the "social control model" is "premised on the state's role in maintaining public

24 Wildeman, Sheldon \& Spector, supra note 2.

25 Ibid.

26 Ruby Dhand, "Creating a Cultural Analysis Tool for the Implementation of Ontario's Civil Mental Health Laws" (2016)

45 Intl JL \& Psychiatry 25; Dhand, "Access to Justice", supra note 1; Ruby Dhand, "Race, Culture and Ethnicity in Mental Health Law and Policy" in Flood \& Chandler, supra note 1, 449; Kwame McKenzie, "We Need to Urgently Address Equity in COVID-19", Toronto Star (16 March 2020), online:

$<$ https://www.thestar.com/opinion/contributors/2020/03/16/we-need-to-urgently-consider-equity-in-our-coronavirusresponse.html>.

27 Trial Lawyers Association of British Columbia v British Columbia (Attorney General) [2014] 3 SCR 31.

28 Isabel Grant, "Mental Health Law and the Court" (1991) 29:4 Osgoode Hall LJ 748 at 748. 
order. The state deprives one individual of liberty in order to protect the welfare and safety of other members of society." 29 Along with a critique of the social control model in mental health law, our legal analysis draws from various theoretical frameworks including administrative justice, access to justice intersectionality. We argue that the onus remains on law-makers, judges, adjudicators and lawyers to challenge the systemic discrimination faced by people with mental health issues during COVID-19. In order to break through institutional barriers effectively and to achieve the necessary transformation of existing cultures, we must first identify and then eliminate discriminatory premises and practices. We can only accomplish this through administrative justice models that are informed by the principles of access to justice and intersectionality.

The Consent and Capacity Board is established pursuant to the Health Care Consent Act, 1996 $[H C C A] .{ }^{30}$ This expert tribunal adjudicates in a variety of matters including, among other things: "issues of involuntary committal and community treatment orders under the Mental Health Act [MHA], consent and capacity issues in relation to treatment, admission to care facilities and personal assistance services under the HCCA, and management of property under both the Substitute Decisions Act, 1992 and the MHA;" ${ }^{31}$ In contrast, the Ontario Review Board is established pursuant to the Criminal Code of Canada. ${ }^{32}$ The ORB is an expert tribunal which makes disposition orders for accused persons who are found by a court to be "unfit to stand trial" [UST] or "not criminally responsible on account of mental disorder" $[\mathrm{NCR}]{ }^{33}$

In this paper, we examine the Consent and Capacity Board [CCB] and the Ontario Review Board's [ORB] initial and ongoing responses to the COVID-19 pandemic. We investigate and consider how these responses relate to procedural, discretionary and systemic barriers to access to justice. We posit that mental health tribunals during the pandemic must accommodate people's rights to substantive and meaningful access to justice and appreciate the lived experience of people with mental health and addictions issues. We conclude that there is an opportunity for mental health tribunals to proactively address the transmission risks of COVID-19 through legal safeguards and procedural fairness to increase access to justice.

In Part I of this paper, we analyze the procedural barriers to access to justice that arose as a result of the initial responses to COVID-19 by the CCB and ORB. In Part V, we include a brief report on how appeals taken from both tribunals have been handled throughout COVID-19 to date. In Part VI, we analyze the discretionary and systemic barriers experienced by people with mental health and addiction issues appearing before the CCB and ORB during COVID-19. We critique recent mental health law cases during COVID-19 where deprivations of liberty interests and substantive equality have occurred, and access to justice for people with mental health and addictions issues has been denied, suspended or impaired. Through a legal analysis of how the pandemic has impacted this vulnerable community of litigants, we hope this research will result in further advocacy and education to prevent outbreaks and death, improve health care practices, and increase access to justice.

29 Isabel Grant \& Peter J Carver, "PS v Ontario: Rethinking the Role of the Charter in Civil Commitment" (2016) 53:3 Osgoode Hall LJ 999 at 1001.

30 Health Care and Consent Act, SO 1996, c 2, s 10-25 [HCCA].

31 Mental Health Act, RSO 1990, c M7; Other types of issues and applications heard by the CCB also include issues arising from the Mandatory Blood Testing Act, 2006; the Long-Term Care Homes Act, 2007; and the Personal Health

Information, Hiltz, Szigeti \& Dhand, supra note 5 at 20; See Consent and Capacity Board (CCB), online:

$<$ http://www.ccboard.on.ca/scripts/english/index.asp> [CCB]; Hiltz \& Szigeti, supra note 5 at 701.

32 Criminal Code, supra note 19, s 672.62; Davies et al, supra note 19 at 45.

33 Criminal Code, supra note 19. Ontario Review Board, online: <http://www.orb.on.ca/scripts/en/>. 


\section{PROCEDURAL BARRIERS: INITIAL RESPONSES BY THE CCB AND THE ORB TO THE GLOBAL PANDEMIC}

By March 11, 2020, the outbreaks of COVID-19 were declared a global "pandemic" by the World Health Organization. ${ }^{34}$ It quickly became clear that in-person court and tribunal proceedings would have to stop and could not be resumed safely for the foreseeable future. On Friday, March 13, 2020, the Consent and Capacity Board and Ontario Review Board hearings were still proceeding in person, in the ordinary course. The CCB holds its hearings with panels of 1,3 or 5 members (adjudicators) most often in psychiatric facilities or general hospitals with psychiatric wards. ${ }^{35}$ Present at CCB hearings are also the patient applicant, the respondent psychiatrist or other health provider, lawyers for one or both parties, the court reporter, and any family members, friends or observers. All these people are crowded into what is usually a small conference room. ${ }^{36}$ The ORB holds its hearings within psychiatric hospitals, ${ }^{37}$ which are facilities that only house psychiatric inpatients, civil and forensic. ${ }^{38}$ There are five members of the hearing panel, the Crown attorney, the presenting psychiatrist or other witness, the hospital's representative, the accused person plus his or her lawyer, and the court reporter present, minimally at least ten people, at every hearing. ${ }^{39}$ There may be other witnesses or supportive family and case-workers in the room, among others. ${ }^{40}$ As a result, social distancing is physically impossible in the hearing rooms historically set aside for this purpose.

\section{A. The Consent and Capacity Board's Initial Response}

The Consent and Capacity Board almost immediately provided a viable alternative to in-person hearings. On March 13, 2020, the Board advised its stakeholders that beginning Monday, March 16, 2020, all matters were to proceed by teleconference. ${ }^{41}$

The Board put a number of new procedures in place to facilitate teleconference hearings including that:

- Parties must ensure all documents are provided to the other parties and the Board no later than 10:00 am the business day prior to the hearing.

- Rescheduling requests will not be considered. Adjournments will be carefully considered and only given if there is no alternative.

- Five daily hearing slots will occur and these differ from normal CCB hearing times (at 8:15 am, 10:45 am, 1:15 pm, 3:45 pm, and 6:00 pm). ${ }^{42}$

34 WHO Director-General's opening remarks at the media briefing on COVID-19 - 11 March 2020 here: WHO $<$ https://www.who.int/director-general/speeches/detail/who-director-general-s-opening-remarks-at-the-media- briefingon-covid-19---11-march-2020>.

35 Mental Health Act, supra note 31, s 39 (14); See also Hiltz \& Szigeti, supra note 5 at 227 and 702.

36 Mental Health Act, supra note 31.

37 These are the former so-called "provincial psychiatric hospitals" which were once owned and operated by the Ontario government, the Ministry of Health. A list of designated facilities which may detain UST and NCR accused is available at "Designated Hospitals Under the Criminal Code and Youth Criminal Justice Act", online: Ministry of Health and Ministry of Long Term Care $\leq$ http://www.health.gov.on.ca/en/common/system/services/psych/designated_cc.aspx >; See also Appendix "G" of $A$ Guide to Mental Disorder Law in Canadian Criminal Justice, Davies et al, supra note 19 at 108.

38 Ibid.

39 Criminal Code, supra note 19, s 672.38, Davies et al, supra note 19 at 108.

40 Ibid.

41 Communications made to all parties and counsel. See also CCB, supra note 31.

42 Ibid. 
By March 16, 2020, the CCB's quick pivot to teleconferencing meant that hearings already booked proceeded as scheduled. The CCB's smooth transition to teleconference hearings meant that the scheduling of new applications was not adversely affected either. The Board was able to commence hearings within the seven-day statutory timeline. ${ }^{43}$

The Consent and Capacity Board also continued to hold its regular "Board and Bar Committee meetings," with representation from lawyers for patient applicants as well as lawyers for hospitals and doctors. ${ }^{44}$ These meetings were held more frequently during COVID-19, intended to allow for a candid discussion among stakeholders to identify and resolve any issues with the new teleconference hearing model. ${ }^{45}$ Over the coming weeks, the Board was flexible in addressing a number of voiced concerns (including cancelling the 6:00 pm hearing slots and ensuring counsel had electronic access to their clients' health records and charting notes). As a result, such electronic access is now routinely provided by hospitals across Ontario. This is a welcome side-benefit of remote adjudication born out of necessity during COVID-19.

The approach adopted by the CCB stands in stark contrast to the Ontario Review Board's [ORB] response to the pandemic. The initial decisions by the $\mathrm{CCB}$ and ORB in response to the pandemic were both made unilaterally. This was to be expected given the emergent nature of the decisions that needed to be made. However, while the CCB's response ensured that all hearings transitioned seamlessly to a new medium without delay, the ORB's response did not. And while the CCB immediately began to receive stake-holder input and continued to liaise with stake-holders throughout, the ORB did not.

\section{B. The Ontario Review Board's Initial Response}

On March 16, 2020, the Ontario Review Board notified parties and stakeholders that they were delisting all hearings scheduled between March 16, 2020 and April 3, 2020. These hearings were to be rescheduled to dates after June $1^{\text {st }} 2020 .{ }^{46}$ The ORB ordinarily hears four matters each day at any given facility. On average, during any one week the Board will convene, hear and determine sixty or more cases across Ontario, if it is sitting in at least three hospitals that week. Three weeks of hearings would ordinarily result in completed adjudication of minimally 180 disposition reviews for NCR accused in this province. The three weeks of hearings that were cancelled for COVID-19 included Annual Disposition Review Hearings ("Annual Hearings"), ${ }^{47}$ and Reviews of significant increases on the restriction of an accused's liberty ("Restriction of Liberty (ROL) hearings").48

Pursuant to s. 672.81 (1) of the Criminal Code, the Review Board is mandated to review the Disposition of every UST and NCR accused under its jurisdiction at least once every twelve months. ${ }^{49}$ At these annual disposition order review hearings, the Board must determine whether the accused person continues to pose a significant risk to the public's safety and if so, what the necessary and appropriate disposition is. The Board must choose between a conditional discharge or a detention order, with appropriate conditions in either case. The disposition must be the least onerous and least restrictive commensurate with the paramount consideration of safeguarding the public's safety. ${ }^{50}$

43 Ibid, s 37.4, "CCB Rules of Practice."

44 CCB, supra note 31.

45 Ibid.

46 Communications made to all parties and counsel. Ibid.

47 Criminal Code, supra note 19, s. 672.81 (1).

$48 \quad$ Ibid, s 672.81 (2.1).

$49 \quad$ Ibid, s 672.81 (1).

$50 \quad$ Ibid, s 672.54. See also Davies et al, supra note 19 at 221. 
Unilaterally cancelling a March hearing date, to be relisted for after June 1, is not a trifling or insignificant procedural step taken by a tribunal. A two to three month delay of an Annual Hearing is not a nominal difference. The Board's annual dispositions have a direct and significant effect on the NCR accused person's liberty. ${ }^{51}$ In the intervening several months, the affected accused were unable to seek a more liberal disposition, such as an order with more passes or privileges, or a Conditional or Absolute discharge from the ORB. For those who ultimately received a more liberal new disposition, or a loosened Warrant, their liberty was more restricted than it needed to be, while their case was delayed. For some accused persons, it was the difference between discharge to a residence in the community versus ongoing detention in the psychiatric facility. For some of those accused persons, detention in the psychiatric facility exposed them to the risk of contracting COVID-19 in the institution, developing severe illness or even dying as a result. ${ }^{52}$ In retrospect at least, we do know that the period of greatest risk of contracting COVID-19 inside psychiatric facilities was very likely the self-same mid-March to June 1, 2020, timeframe. On the jail / prison side, carceral settings were actively being depopulated early on in the pandemic and urgent hearings, including bail reviews, were held to get people out of congregate settings. ${ }^{53} \mathrm{NCR}$ accused under the ORB's jurisdiction whose hearings fell in the March $16^{\text {th }}$-April $3^{\text {rd }}, 2020$ time period were not consulted and certainly did not consent to having their hearings de-listed; particularly without a fixed date for the return of the matter before the Board.

The de-listing of Restriction of Liberty [ROL] Hearings was even more problematic. An ROL hearing is scheduled when the Hospital significantly increases the restriction on a client's liberty. An ROL hearing must be held "as soon as practicable" 54 after the hospital gives notice of a significant increase on the restriction of the accused person's liberty. ${ }^{55}$ Examples of circumstances, which trigger the mandatory notice requirement to hold an ROL hearing include transfer of an accused to a more secure unit within the Hospital, or when the individual is re-admitted to hospital.

Delisting ROL hearings meant that the increase on the affected NCR accused's liberty restriction could then continue at the hospital's discretion, without review by the ORB, until the hearing was rescheduled, two to three months later. An accused person who was admitted to the hospital could be detained there in the meantime. Accused persons who had lost all their privileges may not regain any passes. An accused person who had been transferred to a more secure unit could be held there, at the hospital's discretion, until the ORB rescheduled their statutorily mandated ROL hearing, sometime in June. ${ }^{56}$

Counsel to accused persons immediately communicated their concerns about the delisted hearings and accompanying delay to the Board. Defence-bar and other mental health law volunteer associations also expressed concerns, urging the Board to hold urgent stakeholder consultations to inform its decisionmaking. ${ }^{57}$ They strongly opposed the blanket de-listing/adjournment of all hearings, and offered various suggestions. The Board was encouraged to hold pre-hearing conferences ${ }^{58}$ to assess each case on an individual basis, to examine the nature of the matter and its urgency, and to give clients an opportunity to be consulted on the rescheduling of their own hearings. Proceeding this way would have allowed the

\footnotetext{
51 See Re Runnalls, [2011] OJ No 2121, 2011 ONCA 364, 106 OR (3d) 291 at para 14.

52 See sources at supra note 2.

53 See JS, supra note 17, para 18; Blake, supra note 16.

54 Criminal Code, supra note 19, s 672.81(2.1).

55 Re Saikaley, 2012 ONCA 92, 109 OR (3d) 262; Davies et al, supra note 19 at 127.

56 Saikaley, ibid.

57 Letter from Law and Mental Disorder Association to Richard D Schneider, Chair of the ORB (19 March 2020); Criminal Lawyers Association Letter to Richard D Schneider, Chair of the ORB (19 March 2020).

58 Ontario Review Board, "Rules of Procedure," online: <http://www.orb.on.ca/scripts/en/legal/orb-rules.pdf>, s 29 [ORB, "Rules"].
} 
Board to schedule time-sensitive or contested matters without delay (even if they must proceed by way of teleconference while another mode of hearing was being evaluated by the Board), while adjourning other matters on consent to June.

The Ontario Review Board did not adopt these suggestions. In what manner the Board intended to proceed with hearings scheduled for after April 3, 2020, if at all, also remained a mystery. Stake-holders were not consulted and NCR accused were left in the dark during this otherwise already very stressful period.

On March 31, 2020, the ORB suddenly announced that starting on April $6^{\text {th }}$, all its hearings will proceed as originally scheduled but that they would now be held electronically using Zoom Video Technology. ${ }^{59}$ The news caused chaos on the ground. After weeks of silence, it was a welcome development to hear that hearings would be resuming. However, it shocked the system because there had been no discussion with the major stakeholders. Some hospitals were concerned that Zoom, at the time, did not provide 'end to end' encryption, potentially compromising sensitive medical or psychiatric information of NCR accused persons, which is evidence routinely heard at these hearings. ${ }^{60}$ Given the sensitive nature of the personal health information disclosed at ORB hearings, hospitals questioned whether Zoom was an appropriately secure platform for this unique purpose.

The procedural barriers to access to justice for people with mental health issues and addictions appearing before the Ontario Review Board include accessibility, inclusion and technical issues. Zoom requires a stable internet and a laptop, tablet or smart phone. Individuals with serious mental health and addictions issues (who are outpatients) often live in group homes receiving support through a social assistance or disability program. On balance, they are generally unlikely to have access to electronic devices. Most do not have their own phones, let alone cell phones. They generally use a shared patient / client phone or a phone in an office in their residence. It did not appear that the Board had turned its mind to this reality or that they were even aware of such constraints. It was not at all clear at first whether clients could participate in Zoom hearings by audio only.

Hospitals were unclear if they could, on such short notice, even provide their in-patients with a private room, internet access and a laptop, to facilitate their attendance at the Zoom hearings. Trying to arrange for outpatients to access assistance to participate in ORB hearings proved even more problematic, particularly in those hospitals where COVID-19 positive patients and staff made the facility a dangerous place for NCR accused living in the community to return to, just to participate in a hearing. By that time, many outpatients would report in to their teams remotely, often by phoning in, rather than attend at the hospital. It seems procedurally unfair to require the accused to attend at the hospital and risk contracting COVID-19, just to access a computer in order to participate in their ORB hearing.

On April $1^{\text {st }}$, the ORB announced that they will be conducting "Zoom Demos" with representatives from different parties / stakeholders. ${ }^{61}$ These Zoom Demos were helpful to assist all counsel with the Zoom technology, but they did not touch on the wider legal and access to justice issues raised above.

Regardless, by April 6, 2020, Zoom ORB Hearings were underway. Some identified problems were resolved - for example, all hospitals ultimately agreed to utilize Zoom and facilitated the accused person's participation where necessary. However, concerns at the relevant time about the security of the Zoom

59 Ontario Review Board, "COVID-19 Updates" online: <http://www.orb.on.ca/scripts/en/> [ORB, "Covid-19 Updates"].

60 CBS News, "Zoom Sued for Allegedly Sharing Users' Personal Data with Facebook" (updated 1April 2020), online: $<$ https://www.cbsnews.com/news/zoom-app-personal-data-selling-facebook-lawsuit-alleges/>.

61 Zoom demos were conducted with representatives from each of the designated hospitals (FDG), the Criminal Lawyers' Association, Law and Mental Disorder Association, and hearing counsel from the Ministry of the Attorney General (Ontario). 
platform lingered. While the ORB indicated that accused persons who don't have access to Zoom could simply phone into their hearing, the Board's jurisdiction to hold a hearing where the accused only joins by phone remained questionable and tenuous at best. The other problem is the disparate impact on utilizing video technology when the accused alone lacks the resources to participate on the same footing. If the accused must phone in because they can't access the video technology, they are already at a disadvantage vis $a$ vis the other participants to the hearing, including the Crown, the hospital's representative and the Board members. On the statutory interpretation side, it was not clear what would happen if a client refused to have a video hearing - a problem that materialized for the first time a few months later. ${ }^{62}$

With only a few days' notice, parties and stake-holders were scrambling to facilitate the transition to Zoom hearings and to identify and resolve a number of challenges to the new platform. The transition was chaotic, confusing and riddled with uncertainty. This all amounted to a great lot of unnecessary additional stressors for all involved, which could largely have been avoided had the ORB consulted its stakeholders earlier, or at least if parties were given more than three business days' notice of the Zoom hearings. While the additional stressors were difficult for professional parties and counsel, they were especially disorienting for NCR accused, who also received very short notice of what was happening and who frequently require much in the way of notice and preparation for their annual big day in 'Court.'

\section{THE NEXT PHASE OF THE ORB'S COVID-19 RESPONSE: ADDITIONAL PROCEDURAL FAIRNESS ISSUES ONCE HEARINGS RESUMED VIA THE ZOOM PLATFORM}

\section{A. Remote Hearings - Generally Recognized Impact on Access to Justice}

Scholars have long recognized the multiple barriers to access to justice when using technology. Lorne Sossin contextualizes these issues, which are significantly heightened during COVID-19 for NCR accused appearing before the ORB, as follows:

These issues arise not as an abstract question of fairness but also as a concrete trade-off involving resources. Videoconferencing, for example, is far less expensive than maintaining an office in remote centres or obtaining facilities for in-person hearings. Of course, a hearing by teleconference would be even less expensive. The question is when efficiency or cost-cutting measures begin to erode the fairness of a decision-making process. ${ }^{63}$

\section{B. The Fate of the Cancelled ORB Hearings (March 16-April 03)}

Once the ORB adopted Zoom as its hearing platform during Covid-19, hearings then began proceeding as originally scheduled and essentially in the ordinary course. It was at this point that the unfairness to the clients whose hearings had been unilaterally delisted became especially glaring. There was clear inequity between a client whose hearing had been listed for April $3^{\text {rd }}, 2020$ versus a client whose hearing was scheduled for April $6^{\text {th }}, 2020$. The latter got their timely, statutorily mandated review without missing a beat, while the former was told they would have to wait until after June $1^{\text {st }}, 2020$ for a date to be fixed.

62 Woods v Ontario, 2020 ONSC 6899 [Woods]; Reasons for Ruling dated August 25, 2020, JW (Re) ORB File No 6114, heard via Zoom audio-visual platform on 31 July $2020[\mathrm{JW}]$.

63 Lorne Sossin, "Access to Administrative Justice and Other Worries" in Lorne Sossin \& Colleen Flood, eds, Administrative Law in Context (Toronto: Emond Montgomery 2013) 85.

$<$ https://digitalcommons.osgoode.yorku.ca/scholarly_works/502>; Also, see Jane Bailey, Jacquelyn Burkell \& Graham J Reynolds, "Access to Justice for All: Towards an 'Expansive Vision' of Justice and Technology" (2013) 31:1 Windsor YB Access Just 181. 
Some accused persons whose hearings had been delisted, asked the Board to convene immediately and in any event, before June. They emphasized the importance of a timely annual disposition review, particularly during a global pandemic. Detention in hospital in the age of COVID-19 is significantly more restrictive and onerous than could have been anticipated just a few months prior. Off-ward passes, even with staff, even onto the hospital's grounds were either completely cancelled or significantly reduced. Unaccompanied and community passes were not available to anyone. Even passes for 'fresh air' were strictly limited in time and only accompanied by staff. Most hospitals did not allow clients to smoke anywhere. For significant periods of time during the height of the new COVID-19 cases, no visitors were allowed in psychiatric facilities, including lawyers. Detained accused were not able to have in person contact with their families while COVID restrictions were in place. Some hospitals also implemented new policies suspending all food and parcel deliveries from outside the hospital. The COVID-19 measures implemented by the hospitals by definition increased the restriction on the accused persons' liberties, autonomy and freedom. These restrictions also completely halted their community re-integration. ${ }^{64}$

The already significant liberty restrictions associated with detention in hospital are also further exacerbated during the pandemic, as a result of the disproportionate risks of COVID-19 to psychiatric inpatients. A locked psychiatric ward makes it very difficult, if not impossible, to practise social distancing. Reports received from forensic inpatients indicated that social distancing was not enforced on the units. Detainees were not given masks or gloves when accessing the common areas of the ward, or when using the shared facilities on the unit, such as the phone, TV remote, or computer. These circumstances make a locked psychiatric ward highly susceptible to an outbreak of the virus, and to the rapid, indiscriminate transmission of the virus once it enters the ward. This was particularly concerning given that some hospitals were already experiencing COVID-19 outbreaks on their psychiatric inpatient units. ${ }^{65}$

The circumstances of detention during COVID-19 made ORB hearings especially urgent and time sensitive. It was more important than ever that accused persons be afforded their statutorily mandated review board hearings without any undue delays or additional impediments to access to justice. Some accused who sought to have their delisted hearings rescheduled urgently emphasized these factors and the consequently devastating impact of any delay on their ability to seek their discharge from hospital. ${ }^{66}$

The Board responded appropriately and promptly to these communications. They scheduled prehearing conferences for all clients who complained about their de-listed hearings, and shortly thereafter, the Board scheduled those clients' review board hearings for late April / early May.

While this was certainly a sensible response to those who complained, the problem of course is that other clients, without lawyers or advocates who were prepared to take these additional steps or those who were too vulnerable to complain, were left behind. In choosing only to react to the "loudest" complaints, the Board put an unfair burden on vulnerable persons with serious mental health and addictions issues to take proactive steps and make their case for why they should have their hearing then. This burden ought not to rest on the client. It is the Board's responsibility to comply with Criminal Code provisions and ensure that accused persons are afforded timely hearings. The Board's approach had a disparate impact on self-represented accused or those who were not sufficiently sophisticated to engage in an ad hoc process

64 Letter from Anita Szigeti Advocates to Ontario Review Board (14 April 2020), Re: Glenroy Blake, ORB File No 5692; Letter from Anita Szigeti Advocates to Ontario Review Board (14 April 2020), Re: Jerome Williams, ORB File No 6031.

65 CAMH, "COVID 19 Updates", supra note 14; City of Hamilton, "Status of Cases in Hamilton, (20 July 2020), online: $<$ https://www.hamilton.ca/coronavirus/status-cases-in-hamilton>.

66 Ibid. 
that put the onus on the accused effectively to request his own statutorily mandated hearing. Absent any active steps by the client, it was only in May that the Board re-scheduled the other de-listed hearings for dates in June of 2020.

\section{The "One Representative Per Party" Rule}

Shortly after the ORB adopted Zoom as its hearing platform, the Board decided to allow only one representative per party to join the Zoom meeting via video. ${ }^{67}$ Additional representatives were not permitted to join the meeting by Zoom (even if their video was turned off). Anyone else who wanted to participate or observe the hearing was permitted to phone in. Those observers and participants could only hear, but not see, the proceedings. This posed a serious impediment to access to justice for those accused who were represented by co-counsel. If there were two lawyers for the accused, they were not permitted to appear on video together. This set-up precludes one lawyer from seeing their own client, the panel members, or the testifying witness. Even worse, it deprives the accused person of her right to be represented by counsel of choice because one of her chosen lawyers is shut out of the proceeding.

\section{Where the Accused Refuses to Consent to A Zoom Hearing}

Zoom hearings by the ORB are contingent on the accused's consent to an electronic hearing. The Criminal Code requires the accused's consent in this regard. ${ }^{68}$ The Board's May 25 COVID -19 update provided accused persons with the following options where "an accused has health concerns related to their available mode of connection to the hearing." The accused could:

1) Request to be absent for all or part of the hearing (with counsel in attendance),

2) Phone-in to the hearing, or

3) Seek an adjournment to a time when we will likely have resumed on-site hearings. ${ }^{69}$

The Board's May 25 COVID-19 update also advised that: "for those who have misgivings with respect to the Board's jurisdiction to conduct hearings employing this technology, the alternative would be to apply to have the matter adjourned to a time when we might anticipate a resumption of on-site hearings."70

The Board has since amended this notice on their website. As of October 2, 2020 the Board's website instead advises that: "Any party having reservations with respect to the Board's jurisdiction to conduct hearings employing this technology can apply to have the matter adjourned to a time when we might anticipate a resumption of on-site hearings. Any such application will be considered from all perspectives and, in particular, our paramount consideration, the protection of the public."71 (Emphasis Added)

In one case, the accused refused to consent to proceed by video. In this case, the Hospital was seeking a more restrictive disposition order. ${ }^{72}$ Despite that the Code requires the consent of the accused to attend by video ${ }^{73}$, the Board decided to proceed with the video-hearing without the consent of the accused, and indeed over her objection. In their reasons, the Board framed the request of the accused as an adjournment request for an "indefinite time." The Board held that allowing such an adjournment would lead to an "absurd result" in that the accused would be in control of when her hearing could be held, and that she

67 This alert comes up every time a party logs in to any ORB Zoom hearing.

68 Criminal Code, supra note 19, s 672.5(13).

69 ORB, "Covid-19 Updates", supra note 59.

70 Ibid.

71 ORB, "Covid-19 Updates, supra note 59.

72 Woods, supra note 62; JW, supra note 62.

73 Criminal Code, supra note 19, s. 672.5(13). 
"could thereby delay and avoid any change in her disposition deemed necessary for review by the Hospital and the Board". At the time that this motion was being heard on July 31, 2020, Toronto had entered Phase 3 of its COVID-19 response, permitting indoor gatherings of up to 50 people, with social distancing measures in place. This meant that the Board could, in theory at least, convene an in-person hearing. The Board's Reasons for Ruling did not address why they refused to convene in-person. ${ }^{74}$

On application by this accused to the Superior Court, the ORB's order to proceed by way of videoconference was quashed by a writ of certiorari in Woods $v$ Ontario. ${ }^{75}$ In Woods, the Superior Court of Justice found that the ORB is only authorized by the Criminal Code to proceed with a disposition hearing via videoconference with the accused's consent. The Court found that the ORB exceeded its jurisdiction when it proceeded to hold a disposition review hearing by videoconferencing, absent the consent of the accused and over her objection. Ms. Woods sought an in-person hearing The Board made no effort to determine whether they could hold such a hearing. Instead the Board deferred to a Memo from its Chair regarding COVID-19, which suggested that in-person hearings were not possible. As a result, the Court found that the Board "[mischaracterized] Ms. Wood's request as an attempt to adjourn her disposition hearing indefinitely". ${ }^{76}$ The Court recognized the Charter-protected liberty interests at stake for accused persons at disposition hearings as follows:

"It might also be observed that there is nothing absurd, illogical or unreasonable in the requirement that the Board hold disposition hearings in person unless the accused otherwise agrees. It is a longstanding and fundamental principle of our criminal law that an accused has the right to be personally present at their trial. Although a disposition review hearing before the ORB is not a trial and is conducted in an informal manner, the nature of the liberty interest at stake is every bit as significant as in criminal trials."77

\section{THE NEXT PHASE OF THE CONSENT AND CAPACITY BOARD'S RESPONSE TO COVID-19: ADDRESSING NEW CHALLENGES AND RESOURCE LIMITATIONS}

\section{A. One Size Does Not Fit All: Teleconference Hearings at the CCB}

In contrast to the ORB, the CCB currently does not offer a video hearing option. While the teleconference model adopted by the $\mathrm{CCB}$ has its advantages - it is flexible, easily accessible, and does not require sophisticated technology or internet access - it poses its own set of challenges and limitations. The most prominent limitation of the teleconference hearing model is that it precludes clients from being able to see the witnesses testifying, the adjudicators, or their own lawyers. It also precludes them from being seen. This carries the risk of limiting their ability to meaningfully participate in the hearing and to appreciate fully what is happening throughout their own hearing. Patient applicants are not 'seeing' justice being done; rather, they are only hearing it. Given the fundamental rights being litigated at CCB hearings

$74 J W$, supra note 62. Ms. J. W. brought a Prohibition, Certiorari and Mandamus Application in relation to this Ruling. The application was heard by the Superior Court of Justice (Toronto) on November 6, 2020; Certiorari was granted. The Board's Order to proceed with videoconferencing without consent of the accused was quashed. Woods, supra note 62. In Woods, the Superior Court of Justice found, the "Criminal Code permits the ORB to hold a disposition hearing by videoconference only with the consent of the accused. The ORB exceeded its jurisdiction in deciding to proceed with a videoconference hearing without the accused's consent and over her objections." at para 2. The Board's ultimate disposition detaining the accused person in this case is also under appeal to the Court of Appeal, not yet scheduled.

75 Woods, supra note 62.

$76 \quad$ Ibid at para 41.

77 Ibid at para 36. 
- the right to self-determination, liberty, and autonomy - this can be a significant barrier to access to justice and access to a full and fair hearing, for some vulnerable individual applicants. This is particularly problematic as it disproportionately affects persons with cognitive impairments and/or with language, communication and other intersectional barriers to accessing justice.

There are other logistical limitations to teleconference hearings, when compared with videoconferencing technology, and in particular Zoom, as a platform. For example, a subgroup of participants cannot 'breakout' from the hearing to have a private discussion. If an applicant needs to meet with their lawyer, or if panel members need to deliberate on an issue during the hearing, they must disconnect from the teleconference to do so. In our experience, it is often difficult to reconnect to the teleconference after disconnecting. This is reportedly due to limitations on the use of assigned access codes, which also means that parties may be automatically disconnected once the two-hour limit on hearings is reached. Probably the biggest interference with CCB phone hearings, however, is the inability of patient / client applicants who are phoning in from psychiatric wards, while detained, to mute their phones. Most of the patient phones in these older hospitals do not have 'muting' functionality. CCB hearings where the patient applicant cannot mute their phone, while participating in their hearing, understandably then mean the background noise of the chaotic psychiatric ward reverberates throughout the hearing. This can be distracting to the point that the integrity of the proceeding is compromised because the hearing panel, parties and counsel cannot follow the evidence.

Beyond the availability of 'break-out rooms', easy to mute or turn video off / on features, another clear advantage to Zoom hearings is the ability to "share screens." This feature allows a lawyer cross-examining a witness, for example, to show the document that the lawyer is referring to, on a shared screen. On a phone hearing, the same simple task, which in a hearing room would be accomplished by sliding a document across the board room table to the witness for their review, would take 10-15 minutes to accomplish. Counsel would have to email or fax the document to the witness and all the parties, counsel and the Board and then resume asking questions about it once everyone has received the document.

Most of the CCB's hearings are readily completed within the two hour time allocation as most are reviews of involuntary detention on an initial Form 3 Certificate of Involuntary Admission. These hearings are generally proceeding without incident, by phone. However, certain hearings, particularly those involving complex issues, voluminous documentation, multiple witnesses or the need for interpretation, cannot withstand the greater frequency of disruptions and logistical complications inherent in teleconferencing. Hearings of applications that necessarily involve difficult emotionally-laden evidence, where a number of family members are pitted against each other in deeply held disputes over what to do in tragic medical circumstances, such as end of life treatment decision cases, are also extremely challenging to conduct over the phone. Lengthy hearings, over two hours in duration, require significantly more effort to follow along when conducted on the phone, as opposed to by videoconferencing. All of these cases, which even when combined would still constitute only a relatively small percentage of the CCB's hearings, would benefit from a video-conference option.

Flexibility in accommodating the most appropriate mode of electronic hearing would be a very welcome development in mental health adjudication. While it is possible to phone into the ORB's Zoom hearings, the CCB currently does not have a video hearing option. At the time of writing, the CCB is offering only teleconference hearings. The Board has communicated that it is not opposed to video conferences in principle, but has not set up the capability to host a video conference hearing itself. Therefore, if a party requests that their CCB hearing be held by video, this can only be accommodated if one of the parties to the hearing is prepared to host that meeting on a video-conferencing platform ${ }^{78}$.

$78 T M(R e), 2020$ CanLII 32318 (ON CCB) [TM]. 


\section{B. Mandatory Community Treatment Order [CTO] Review Hearings Not Scheduled}

Community Treatment Orders [CTOs] are issued by physicians with the consent of the capable subject or the incapable person's substitute decision maker. ${ }^{79}$ They require compliance of the individual who is the subject of the underlying Community Treatment Plan with that plan, which inevitably hinges on the requirement to take psychiatric medications, under pain of being forcibly returned to the issuing physician for an examination and risking an involuntary hospitalization for failure to comply. These are seriously coercive legal mechanisms of social control. Because of the extraordinary vulnerability of those who are subjected to such orders, particularly over their objection and pursuant to someone else's consent on their behalf, the Mental Health Act, s. 39.1 (3) has ensured that the criteria for issuing and renewing such CTOs (every six months) are mandatorily and automatically reviewed on the occasion of every second renewal, so practically speaking annually, by the $\mathrm{CCB} .{ }^{80}$ This procedural safeguard and access to justice measure, was enacted to ensure that vulnerable individuals' legal rights are respected, particularly in the context of the onerous liberty-restricting nature of Community Treatment Orders.

While we are not aware of any announcement in this regard, a close look at some mandatory CTO review cases ultimately heard during COVID-19 would suggest that the CCB stopped scheduling these hearings at the start of the global pandemic. From the Reasons in two CCB cases $\left(L P^{81}\right.$ and $\left.A A^{82}\right)$ it appears that the CCB may have suspended the scheduling of mandatory CTO hearings for at least a month upon the rise of COVID-19. The mandatory CTO hearings for both $L P$ and AA were delayed by almost three months, for reasons that are still not clear. The respondent psychiatrist in $A A$ testified that he was told (by the hospital in this case) that the CCB stopped scheduling these hearings between March 16, 2020 and April 22, 2020. This was never confirmed by the Board. However, if this was indeed the case, it was never communicated directly to any of the clients whose mandatory CTO hearings were outstanding. In both $L P$ and $A A$, the Board revoked the CTOs because they were not reviewed within seven days of the physician's notice given to the Board of the need to schedule the mandatory CTO review hearing. ${ }^{83}$ Both cases implicitly acknowledge that the failure to schedule these mandatory hearings, for whatever reason, denied the vulnerable subject of the CTOs access to justice and amounted to a violation of those individual's rights to their hearing within the statutory timelines.

\section{LESSONS LEARNED FROM ONTARIO'S MENTAL HEALTH TRIBUNALS' PROCEDURAL RESPONSES TO COVID- 19}

Despite that there are lessons to be learned going forward from the divergent approaches taken by Ontario's civil and criminal mental health tribunals, we have to acknowledge the leadership shown by each in its own way during unprecedented circumstances of a global pandemic. Both tribunals had to make very difficult decisions essentially overnight and in response to a situation that could not have been and was not anticipated, or contemplated by their enabling legislation. We readily acknowledge no decision taken under these trying circumstances is going to be perfect. Whatever options to resume operations are selected, none will equate with in person hearings. All modes of electronic or remote hearings will present their own unique challenges and have their limitations.

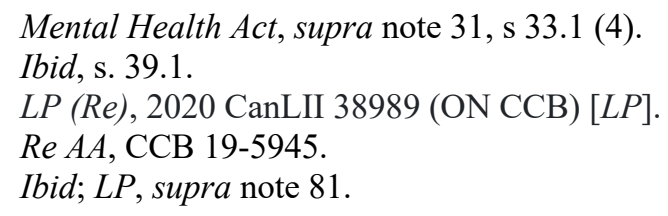


We suspect that the Consent and Capacity Board was able to continue its hearings essentially uninterrupted in part because it had experienced something similar to COVID-19 during the 2003 outbreak of SARS. Because it holds its hearings in general hospitals with psychiatric wards, during the SARS epidemic, the CCB could not hold in person hearings in those facilities. At that time, it instituted and implemented what it called the 'SARS protocol', ${ }^{84}$ including the option of teleconference hearings. It had previously had occasion to address similar issues, as arose in the context of COVID 19, once before. As a result, it had the institutional memory and preparedness to respond to some of the challenges posed by COVID-19. Its transition to electronic hearings was also easier because, unlike the Criminal Code, the CCB's enabling statute (the $H C C A$ ) does not limit or prohibit teleconference hearings. The ORB did not have the same prior experience on which it could rely, as they did not have to develop a protocol in response to SARS, given that all the ORB's hearings are held in psychiatric hospitals, within which SARS was never a concern. ${ }^{85}$

Recognizing the efforts made by the CCB and ORB and acknowledging limitations out of their control, there nonetheless remain opportunities to learn from both tribunals' responses not only initially but throughout the pandemic thus far. We are highlighting the importance of some access to justice issues identified so far to assist all justice system participants going forward. COVID-19 is likely to continue to pose significant challenges and render in person hearings impossible for some time to come yet. Access to justice for all persons with mental health issues should always be at the forefront of tribunals' minds. Consultation with individuals with mental health issues and their advocates is extremely important and should not be overlooked. The experiences and opinions of patient applicants to the CCB and NCR accused persons at the ORB are likely to be the most helpful in gauging what works and what does not. Their voices cannot be discounted because they have mental health issues. Meaningful access to justice mandates inclusion of the client groups in consultations and developing policy and practices that directly affect adjudication of their liberty interests and other Charter-protected rights.

\section{A WORD ABOUT APPEALS AND PROCEDURAL BARRIERS}

\section{A. Appeals from the Consent and Capacity Board}

Parties to proceedings of the CCB have a statutory right of appeal to the Ontario Superior Court of Justice on any question of fact or law. ${ }^{86}$ In every appeal, the Board is tasked with obtaining the transcript of the proceeding and compiling, serving and filing the appeal record. ${ }^{87}$ During COVID-19, the Board temporarily stopped serving and filing these materials. ${ }^{88}$ This was in response to the Court's

84 During the SARS pandemic, general hospitals (where many CCB hearings occur) were operating under "code orange," restricting lawyers hospital access pursuant to the SARs hospital directives. In response, the CCB created the "SARs protocol" to ensure teleconference hearings were an accessible and alternative option. Such a protocol was not developed for the ORB because it was not necessary. Suzan E Fraser, "Effect of SARS Restrictions on Access to Justice for Consumers and Survivors of Mental Health Services” (Presentation Brief, SARS Commission, Public Hearings 2003, Toronto).

85 Designated Hospitals under the Criminal Code and Youth Criminal Justice Act, and Youth Criminal Justice Act, as published by the Ontario Ministry of Health and Long Term Care; Ontario Health $<$ http://www.health.gov.on.ca/en/common/system/services/psych/designated_cc.aspx\#two>

86 HCCA, supra note $30, \mathrm{~s} 80$.

87 Ibid, s 80 (4).

88 See CCB, supra note 31. More recently, if parties or counsel represent to the CCB that the appeal is going ahead to hearing, the Board will now prepare, serve and file the Transcript and Record in relation to that particular appeal. 
announcement that it would continue to hear only certain matters, which it considered to be 'urgent" ${ }^{\text {' } 9}$. CCB appeals were not on that list. The Court ceased hearing these appeals effective March 17, $2020^{90}$. Indeed, the Court initially refused to receive Notices of Appeal from CCB matters, which are required by statute to be filed within seven days of the Decision. ${ }^{91}$ Despite the strict statutory limitation period on filing appeals from the CCB and despite the Charter protected rights at stake, we are aware of a number of cases where the Court did not accept in-person or electronic filings of Notices of Appeal from the CCB, as they were not classified as sufficiently 'urgent' to merit filing. However, in our experience in Toronto, the court has recently begun accepting all Notices of Appeal from CCB matters and has again allowed in person filing in the ordinary pre-Covid course.

Throughout the pandemic to date, the Court has also been considering motions brought by parties to have their matter declared as 'urgent'. ${ }^{92}$ If this motion is allowed, the Notice of Appeal is accepted and the appeal will be processed. As a result, a practice developed where counsel, who were seeking to file a Notice of Appeal, appended a covering letter explaining the urgency of the particular matter to be filed. Whenever a Notice of Appeal from a CCB matter was successfully filed, the Court responded immediately by scheduling a case-conference. Once the initial urgency threshold was met, the Court did in fact prioritize hearing these appeals and case managed them throughout.

Since the Court had otherwise suspended hearing treatment capacity appeals from the CCB during COVID-19, some doctors brought section $19^{93}$ motions pursuant to the $H C C A$ seeking an order permitting treatment pending appeals. ${ }^{94}$ Some physician respondents urged the Superior Court to hear and determine the capacity appeals as "urgent," where the Appellant was deteriorating significantly while the Court was not hearing these appeals during COVID. ${ }^{95}$ Where amicus curiae was required to facilitate hearing of the appeal due to a refusal by Legal Aid Ontario to fund counsel for the Appellant or because the Appellant refused counsel, these appointments were made by the Court to ensure 'urgent' appeals were heard and determined promptly despite COVID-19 restrictions. $^{96}$

\section{B. Appeals from the ORB to the Ontario Court of Appeal}

By contrast, appeals from the ORB continued essentially uninterrupted. The ORB's Dispositions are appealed as of right directly to Ontario's Court of Appeal. ${ }^{97}$ The appeal rights are also broad and may be based on any error of fact or law. ${ }^{98}$ The ORB is not tasked with preparing the appeal record or obtaining transcripts but must forward the original papers to the Court when there is an inmate appeal before the Court from the Review Board. The Court very quickly revised service and filing requirements to allow for electronic service and filing. On these appeals the Crown has prepared and filed transcripts and records electronically throughout the pandemic to date.

89 Superior Court of Justice, "Suspension Notice to the Profession, the Public and the Media Regarding Civil and Family Proceedings" (1 November 2020), online: <https://www.ontariocourts.ca/scj/covid-19-suspension-fam/> [SCJ, "Suspension Notice"].

$90 \quad$ Ibid.

91 HCCA, supra note 30 , s 80 (2).

92 SCJ, "Suspension Notice", supra note 89.

93 HCCA, supra note 30, s 19.

94 Almeida v Morgan, 2020 ONSC 2192 (CanLII) [Almeida]

95 See e.g. Shahwan v Dr. Harrigan, CV-19-00615912-0000. Decision is under reserve.

96 Almeida, supra note 94.

97 Criminal Code, supra note 19, s 672.72.

98 Ibid. 
The Ontario Court of Appeal prioritized these appeals as urgent and continued to hear them either remotely via videoconferencing or in writing if parties agreed. As a result, appeals from the ORB continued in the ordinary course. New inmate notices of appeal continued to be filed within the statutory timelines $^{99}$ and appeals were scheduled and heard in a timely fashion, albeit, at first with some casemanagement from Justices of the Court, largely to determine the method of hearing.

Appeals of ORB dispositions are of the utmost importance to the NCR accused / appellants whose liberty interests are always at stake. Processing and hearing these appeals took significant collaboration and co-operation among all parties, counsel and the Court, all of whom worked well together to streamline these appeals. The Ontario Court of Appeal has historically held regular stake-holder meetings in relation to these appeals and continues to do so throughout the pandemic. This process allows the Court to receive feedback respecting the mode of hearing, and any issues related to procedural or substantive access to justice in the Court as experienced by the NCR appellants. One example of flexibility that is enormously helpful for NCR appellants on ORB appeals is the Court of Appeal's willingness, now that it is using Zoom as its hearing platform, to promote the appellant to a participant during the hearing of the appeals. That means ORB appellants are seen on video and are able to see the proceedings, as they would if they were sitting in the gallery of the Courtroom in person. While they're not expected to speak, they are able to participate meaningfully in their appeal by hearing and seeing the whole appeal argued.

\section{DISCRETIONARY AND SYSTEMIC BARRIERS: SUBSTANTIVE RESPONSES TO COVID-19 BY THE CCB AND THE ORB}

In this section, we examine discretionary and systemic barriers to access to justice experienced by people with mental health and addictions issues appearing before these tribunals. We highlight a number of recent $\mathrm{CCB}$ and ORB decisions, where COVID-19 arguments were raised. In reviewing these cases, we maintain our overarching position that there is greater potential for adverse effect from COVID-19 for our clients detained within psychiatric facilities than if they were to be released into the public. Involuntary detention on a psychiatric unit elevates the physical risk of contracting COVID-19 due to the congregate nature of the setting, and enhances the potential for serious psychological harm for these vulnerable individuals. The analysis is mindful of the Charter-protected liberty interests at stake; significant liberty restrictions resulting from psychiatric detention are exacerbated during COVID-19 generally and even further escalated in the event a psychiatric detainee contracts the virus. We also highlight a number of bail review cases where courts addressed COVID-19 arguments and recognized how the COVID-19 transmission risks are "significantly higher" ${ }^{100}$ in congregate care facilities. ${ }^{101}$ Depopulation measures (including broad availability and strict enforcement of legal / procedural

99 The statutory deadlines are 15 days from receipt of Reasons of the Board, ibid, s 672.72 (2).

100 JS, supra note 17 at para 19.

101 Also, note the Ontario Court of Appeal's governing bail case on the impact of COVID-19 in the bail review context (Criminal Code, s. 680): $R v J A, 2020$ ONCA 660. The OCA found that COVID-19 can affect all three grounds for detention in a bail hearing (para 63-65). The Court found: "The relevance and materiality of the COVID-19 pandemic requires a review of: a) The respondent's age and health; b) The conditions at the institution in which the respondent would be detained; c) The effect of COVID-19, if any, on whether the respondent will attend court as required; and d) The effect of COVID-19, if any, on the threat posed to public safety by the respondent's release" (para 66). Despite the fact that the OCA reinstated J.A.'s detention and the Crown's appeal was allowed, the majority and dissent agreed on the following: "1. COVID necessarily informs the tertiary ground and has the potential to go to any of the grounds for detention; 2. It is not necessary to show particular health concerns or to be at increased risk to have a bearing on detention; and, 3. A final balancing and proportionality analysis must take place in all considerations of bail". Email from Criminal Lawyers' Association, "Announcement on COVID-19 Bails" (22 October 2020) on file with authors. 
safeguards) were employed to reduce public health risks of COVID-19 and increase access to justice for vulnerable populations.

Despite the differences in the nature of the issues under review in CCB and ORB hearings, both tribunals have responded similarly to COVID-19 arguments raised on behalf of patient applicants at the CCB and NCR accused at the ORB. On balance, both tribunals struggle mightily to appreciate that psychiatric hospitals pose a public health risk to the patients and staff during COVID-19, by virtue of being congregate settings with the necessarily elevated risk of virus transmission. The CCB and ORB tend to view the psychiatric facility as a safe haven that provides the detained individual refuge from the dangers of the outside world and COVID-19, and as a place to keep the public safe from potentially dangerous persons. Our review of the jurisprudence exposes the emerging access to justice issues that are at play in the litigation of the impact of COVID-19 on psychiatric detention and Charter-protected rights of involuntarily detained psychiatric inpatients.

\section{A. Ontario Review Board Decisions}

There are only a handful ORB cases where the accused raised substantive COVID-19 arguments and the Board took the issue into consideration when making their decision or disposition on an accused's ROL or Disposition Review Hearing. The fact that there are so few ORB decisions that have addressed the merits of these arguments indicates that a myriad of access to justice issues remain significantly unresolved. ${ }^{102}$ Throughout our analysis, we highlight the voices of the accused. We demonstrate the ways in which NCR accused have been disproportionately vulnerable to the impact of the pandemic while involuntarily detained in forensic psychiatric facilities.

Counsel have also advanced COVID-19 concerns to request ROL or Early Disposition Review Hearings for their clients, highlighting the specific impact of COVID-19 on the accused's detention under the Board. These accused asked the Board to hold a) hearings to review the additional restrictions on the their liberty due to COVID and/or b) early review hearings to seek a discharge disposition both in an effort

102 In Moore (Re), [2020] ORBD No 1031, the ORB agreed to take tribunal notice "that transmission of the COVID-19 virus is more likely in more densely populated settings". Further, in Soor (Re), [2020] ORBD No 1289, the ORB was "concerned" about the covid-19 restrictions imposed on the detained accused, and the hospital's "inability to contemplate even starting the most limited form of community access, such as going out of doors onto hospital grounds" (para 36). The ORB concluded that they "strongly recommend" and "hope" that "the hospital will make its best effort to assist Mr. Soor to access outdoor and community privileges" (para 36). In Carangay (Re), [2020] ORBD No 1713, the ORB found: "Mr. Carangay's progress has been impeded by COVID restrictions, and we accept that the crisis should not be invoked to justify a detention disposition when a conditional discharge is otherwise appropriate. However, the crisis must not be invoked to reach an inappropriate disposition that would ignore our responsibility to give paramount consideration to public safety. Collateral consequences cannot be allowed to affect a determination of the least onerous, least restrictive disposition" (para 58). Further, in Vrieling (Re), [2020] ORBD No 1645 and Lariviere (Re), [2020] ORBD No 1658, the ORB cited COVID-19 as part of the rationale for re-admitting the patients back to the hospital in the ROL hearings. In Lariviere (Re), the ORB found as follows: "The Board agrees with the joint position of the hospital and Crown and accepts the uncontradicted evidence of Dr. Milhowich that Mr. Lariviere's inability to comply with the safety procedures in place at his community residence resulted in a situation where it was necessary and appropriate to readmit him to the hospital on April 20, 2020. While in the community, his behaviours were putting members of the public, including staff and co-residents, at risk as he refused to comply with safety protocols necessary in the context of COVID-19" (para 35). Similarly, in Vrieling (Re), the ORB found that, "in days prior to the April 28, 2020, Mr. Vrieling was decompensating. He was intentionally placing himself in close proximity to others at the local bus station and within stores so that he could be 'clobbered' or severely beaten and subsequently resurrected thereby fulfilling his prophecy. Mr. Vrieling is 85 years old and at high risk from COVID -19 due to his advanced age and because he was recklessly approaching others in the community thereby exposing himself to the virus as well as placing others at risk of infection were he to contract COVID-19" (para 16). 
to depopulate the institution for the global good and to prevent the accused's own exposure to the risk of contracting COVID inside. The legal analysis of those cases identifies a consistently recurring and devastating blow to the liberty interests and disproportionate impediment to access to justice for this extraordinarily vulnerable group. These cases highlight the ORB's use of administrative discretion to consistently deny NCR accused their requests for ROL and Early Disposition Review Hearings in the context of Covid-19. In denying the accused's requests for additional due process rights, the Board relied on some combination of the following assertions:

1. COVID does not constitute a 'material change of circumstances' necessitating a hearing; 2. The hospitals acting on 'recommendations' of public health is surely in order and not for the ORB to review; and

3. The hospital must have good reason to keep people detained right now and COVID-19 generally is no reason to review that discretion.

In the analysis, we submit that the ORB has a heightened responsibility, particularly during COVID-19, to ensure the health and safety of people with mental health and addiction issues under its jurisdiction. In this section, we analyze the cases where evidence was brought before the ORB to suggest that keeping the accused in hospital during COVID-19 compromises the public's safety. Involuntary detention in hospital is not protective of the accused's Charter-protected liberty and substantive equality interests nor is it necessary or appropriate. We posit that the ORB must recognize that depopulation is the only way to reduce the residual transmission risks to those who cannot be released from psychiatric facilities during COVID-19.

\section{Alexander (Re)}

The ORB considered COVID-19 arguments in Alexander $(R e) .{ }^{103}$ On February 7, 2019, Sandra Alexander was transferred from a general level (minimum secure) ward to a more secure forensic unit with increased liberty restrictions at the Centre for Addiction and Mental Health [CAMH]. CAMH's coronavirus update (dated April 8, 2020) indicated the unit on which Ms. Alexander was now detained (Unit 3-5) had a confirmed COVID-19 outbreak. ${ }^{104}$ On April 8, 2020, the ORB convened to review her Restriction of Liberty pursuant to section 672.81(2.1) of the Criminal Code. ${ }^{105}$

Ms. Alexander's treating psychiatrist testified that Ms. Alexander was "clinically ready" to be transferred back to a general minimum secure unit, but "a transfer is not currently possible due to a suspension of all transfers from her unit because of the state of emergency caused by the COVID-19 virus and bed availability. ${ }^{106}$ Dr. Swayze further "indicated that he and another staff member were in contact with a patient who was positive for the virus on March 26 at which time he left the hospital in order to self-isolate." $" 107$

At the hearing, Ms. Alexander testified that she was, in effect, afraid for her life on that unit: "She stated it was "scary" and that there were individuals on the unit who were extremely ill and violent. She indicated that she did not feel safe and that she had observed assaultive behaviour and that although patients were being told to stay six feet back from each other this was not being followed by all patients.

\footnotetext{
103 Alexander (Re), [2020] ORBD No 779 [Alexander].

104 CAMH, "COVID 19 Updates, supra note 14.

105 Alexander, supra note 103 at para 7.

106 Ibid at para 23.

107 Ibid.
} 
Patients were not being provided with any protective clothing although staff were provided with such clothing. As well, she indicated that patients in seclusion were allowed into the doorways of their rooms." 108

On behalf of Ms. Alexander, counsel argued that the continued liberty restrictions and the impact of COVID-19 were putting Ms. Alexander's "life at risk." ${ }^{109}$ Counsel urged the Board to consider "the impact of the current pandemic on [the] client's life, mental health and liberty interests." 110 Counsel submitted that detaining Ms. Alexander on a unit that has a confirmed COVID-19 outbreak is a breach of her Charter-protected section 7 right to security of the person. "She submitted that as a Board of Inquiry the panel could require that the hospital provide further information on the conditions on that unit and the hospital's plans for ensuring the safety of the patients there." 111

The Board rejected these arguments and unanimously determined that the significant increases on the restriction of Ms. Alexander's liberty were "warranted and constituted the least onerous and least restrictive option available given the circumstances." 112 The Board declined to inquire further into the conditions of the accused's detention on a unit with a confirmed COVID-19 outbreak, and dismissed the argument that it was required to do so in order to make a Charter-compliant disposition order. Instead, the Board found itself somehow without jurisdiction to consider these issues, in effect. The Board refused to address the alleged potential section 7 Charter breaches through the spread of COVID-19 within Unit 3-5, and instead made these findings: "although this Board is an expert tribunal and has a responsibility to inquire into issues before it, its expertise is in the area of mental health, and not in the area of disease control or workplace safety. In our view making a finding as suggested is not within the purview of the Board." 113 The Board found that it "is not qualified to make determinations with respect to public health nor is it qualified to direct that the hospital act in contravention of directives from public health authorities." 114

In this somewhat paradoxical ruling, the Board appears to be suggesting that it is not open to it to use its inquisitorial powers to inquire into any area in which it is not already expert. A lack of expertise, when you are tasked with a duty to inquire, is no reason not to require the relevant subject matter expert to provide the tribunal with the information necessary to make the least onerous least restrictive decision commensurate with the public's safety, including on an ROL review hearing like this one. By dismissing Counsel's submissions regarding the safety concerns of the accused, the viral transmission risks to her and the significant restrictions on her liberty, the Board failed to analyze or meaningfully acknowledge the significant psychological impact and physical danger of the threat of COVID-19 transmission on locked psychiatric wards on vulnerable clients such as Sandra Alexander. The Board refused to take into account the comparative impact on the restriction of the accused's liberty when detained on a unit with an existing current and confirmed outbreak of COVID-19 versus transfer of her to another less secure unit where COVID-19 was not a transmission risk or to release her from psychiatric detention altogether. The Board went further in refusing to inquire into these issues, citing its own lack of expertise. A lack of expertise, respectfully, when you are tasked with a duty to inquire, is no reason not to require the relevant subject matter expert to provide the tribunal with the information necessary to make the least onerous least

\footnotetext{
108 Ibid at para 27.

109 Ibid at para 33.

110 Ibid at paras 39-41.

111 Ibid at para 42

112 Ibid at para 36.

113 Ibid at para 46.

114 Ibid at para 43.
} 
restrictive decision commensurate with the public's safety, including on an ROL review hearing like this one. ${ }^{115}$

\section{Scalabrini $(\operatorname{Re})^{116}$}

In Scalabrini ${ }^{117}$ the ORB again dismissed the COVID-19 arguments of the accused. Jean-Paul Scalabrini was subject to a detention order with community living ${ }^{118}$ and was residing in the community at the time of his hearing on April 6, 2020. The hospital and Crown sought to continue the detention order. Mr. Scalabrini's position was that he was entitled to an Absolute Discharge, or, in the alternative, that a Conditional Discharge was the necessary and appropriate ("least onerous and least restrictive") disposition. $^{119}$

Counsel to the accused made submissions about the impact of COVID-19. ${ }^{120}$ Counsel to Mr. Scalabrini submitted that the "presence of the COVID-19 virus in CAMH was a factor to be considered on the decision to readmit a patient" and "that the necessary and appropriate Disposition was a Conditional Discharge, so that Mr. Scalabrini could not be admitted to hospital throughout the reporting year unless he met the criteria under the $M H A . "{ }^{\prime 21}$ Mr. Scalabrini's attending psychiatrist agreed that Mr. Scalabrini "had not caused any physical harm to others since the index offences"122, and acknowledged the increasing number of people who tested positive for COVID-19 at CAMH. ${ }^{123}$ However, the board unanimously rejected the COVID-19 arguments for a Conditional Discharge disposition for this accused. They maintained Mr. Scalabrini's Detention Order. ${ }^{124}$

\section{Blake $(\operatorname{Re})^{125}$}

In Blake (Re), the accused, who was subject to a detention order of the Board ${ }^{126}$ sought to be discharged subject to conditions at his April 29, 2020 hearing. ${ }^{127}$ Supported by an affidavit ${ }^{128}$ by infectious diseases specialist Dr. Aaron Orkin and other evidence, counsel for Mr. Blake submitted that "the Board must take full account of the public safety threat of COVID-19," 129 as well as the risk of COVID-19 to Mr. Blake, in deciding a disposition. At the time of the hearing, there had been two deaths from COVID-19 at

115 For an analysis of the types of public health considerations involved, see Jennifer A Chandler et al, "Weighing Public Health and Mental Health Responses to Non-Compliance with Public Health Directives in the Context of Mental Illness," in Colleen M Flood et al, Vulnerable: The Law, Policy and Ethics of COVID-19 (Ottawa: University of Ottawa Press, 2020), online: <https://ruor.uottawa.ca/bitstream/10393/40726/4/9780776636429_WEB.pdf>.

116 Scalabrini $(R e)$ is an unreported decision of the ORB, ORB File No. 6362, reasons dated 7 May 2020, NB: this Disposition is under Appeal to the Court of Appeal of Ontario [Scalabrini].

117 Ibid.

118 Ibid at para 23. The accused was ordered detained at the General Forensic Unit of CAMH following a Disposition dated 9 April 2019.

119 Ibid at para 6.

120 Ibid at para 25; Centre for Addiction and Mental Health, "COVID-19 Updates" (8 April 2020), online: $<$ https://www.camh.ca/en/camh-news-and-stories/camh-daily-update--april-8-2020>.

121 Scalabrini, supra note 116 at para 25.

122 Ibid at para 12.

123 Ibid at para 25.

124 Ibid at paras 27-28

125 Blake, supra note 16, NB: this Disposition is under appeal to the Court of Appeal for Ontario.

126 Mr. Blake was detained on the General Forensic Unit at CAMH under a disposition dated March 26, 2019.

127 Blake, supra note 16.

128 Ibid. See also, sources at supra note 17.

129 Ibid at para 40. 
CAMH. ${ }^{130}$ Given the COVID-19 risks, counsel to Mr. Blake submitted that he must be conditionally discharged, noting that "there is no benefit in returning him to hospital at the first sign of trouble," 131 and that doing so would place Mr. Blake at "enormous risk from COVID-19, and for that reason is risk enhancing rather than risk diminishing". ${ }^{132}$ It was submitted that "Mr. Blake should only be hospitalized when he meets the criteria under the MHA, and should not be held for a moment longer than the MHA criteria permits." 133

In this case, the ORB accepted that there is some 'overlap' between a review board hearing and a bail proceeding to the extent that both are concerned with "public safety." 134 The Board acknowledged that they had received materials that were 'helpful' but yet of 'limited relevance' including "up-to-date case law from the parties on COVID-19's impact on the decision whether to grant bail." 135 The Board ultimately accepted some similarities with the bail review jurisprudence but also noted some differences. In the end, the Board nonetheless relied on a bail review case where the Court detained the individual who was denied bail as effectively just too dangerous to release. ${ }^{136}$ This hearing panel indicated that it had "taken COVID-19 into account in determining whether a detention order entails an inappropriate risk of exposing Mr. Blake to the virus." 137 They did not specifically consider Dr. Orkin's Affidavit or the COVID-related patient deaths at CAMH. Arguments on behalf of Mr. Blake included the suggestion that it should be onerous to re-admit him to hospital because the hospital is now a dangerous place due to COVID-19. ${ }^{138}$ The Board did not appear to wrestle with the need to depopulate the psychiatric facility to reduce the risk of COVID-19 to those who must remain detained, but rather chose to analyze the risk COVID-19 poses to outpatients at CAMH on a very narrow basis as highlighted below:

The hospital confirmed that there have been no outbreaks on the West Wing, where Mr. Blake is required to report five times a week. The further risk of exposure to COVID-19 on a detention order is speculative because it is contingent on Mr. Blake's re-admission to hospital as an inpatient. The Board notes that Mr. Blake can mitigate this risk by complying with the conditions of his discharge to the community. ${ }^{139}$

\section{Williams $(\boldsymbol{R e})^{140}$}

In Williams (Re), ${ }^{141}$ Jerome Williams was detained at St. Joseph's Healthcare Hamilton on a Detention Order. At his hearing, he sought a Conditional Discharge to his mother's home or to his friend's house. The treatment team's position was that Mr. Williams was clinically ready for discharge at the time of the hearing, but only to the supported housing facility, Baldwin House. Although Mr. Williams was "next in line for a bed at Baldwin House,"142 they were not admitting new residents because of COVID-19. Mr.

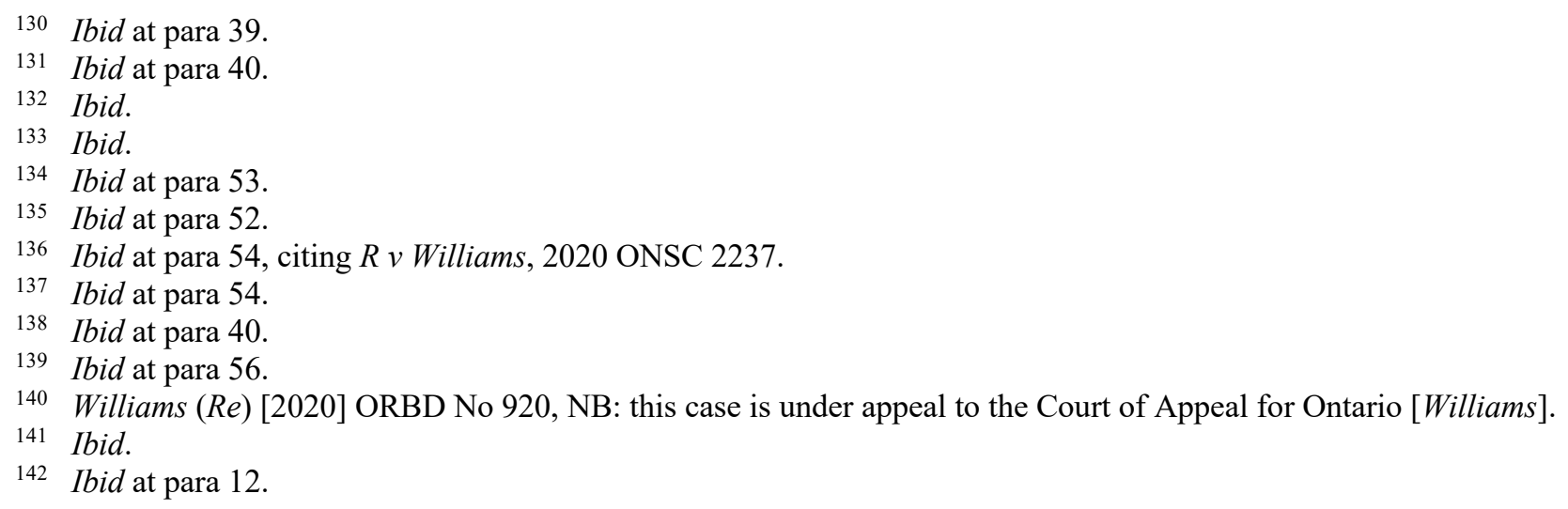


Williams' attending psychiatrist emphasized that it was important 'to have the ability to approve Mr. Williams' housing."143

Prior to COVID-19 policies implemented by the hospital, Mr. Williams had significant privileges into the community, including passes to visit his mother for 72 hours and visits to see his 18 month-old baby. ${ }^{144}$ All these passes had been suspended due to COVID-19. Counsel for Mr. Williams argued that the detention order was "overly restrictive," 145 and emphasized the risk of COVID-19 to Mr. Williams in the Hospital. The Board dismissed the COVID-19 related arguments and Mr. Williams' vulnerability to the virus. The Board failed to take into serious account the significant impact of COVID-19 on Mr. Williams' liberty, autonomy, health and safety when they refused to order him discharged to the community as had been the plan previously, but for COVID-19. Instead, the Board invalidated Mr. Williams' own lived experiences by refusing to recognize the disparate impact of COVID-19 on detained psychiatric inpatients resulting from the extreme restrictions on their liberty during the pandemic. The Board chose to equate Mr. Williams' situation, in effect, with their own. The Board found that the: "COVID-19 pandemic has seriously impacted Mr. Williams' life as it has every other resident of the Province of Ontario."146

\section{B. Requests for Early Review Hearings:}

\section{"COVID does not constitute a 'material change of circumstances' necessitating a hearing”}

Some accused requested an Early Review Hearing ${ }^{147}$ based on COVID-19. Unlike when the hospital requests such a hearing, early review hearings requested by accused persons are discretionary. ${ }^{148}$ In every such case known to us, the ORB has declined to convene a hearing where COVID-19 was the basis for the request, whether generally or due to a confirmed outbreak within the hospital where the accused was detained. For example, Mr. A.A. ${ }^{149}$ an NCR accused detained on a secure unit at CAMH, requested an Early Review Hearing and a Restriction of Liberty Review ${ }^{150}$. His lawyer made the following submission regarding the significant impact of COVID-19 on Mr. A's liberty, in support of his request for an early hearing:

There has been a material change in the circumstances of his detention since his last disposition review on September 26, 2019; namely (1) the hospital's measures in response to COVID-19 make Mr. A.'s detention order significantly more restrictive than could have been anticipated at the time of his annual disposition review, and (2) Mr. A., as an inpatient on a closed and locked psychiatric ward, is exposed to a disproportionately high risk to his health and life due to COVID-19; a risk which unfortunately have materialized in Mr. A.'s case, and (3) Mr. A. currently is in on an isolation unit on the Secure Forensic Unit 3-3, in complete seclusion and isolation, with no access to fresh air. ${ }^{151}$

On May 1, 2020, the Board dismissed these arguments finding that "COVID-19 does not constitute a change of circumstances that would mandate an Early Hearing." 152 This position was reinforced in relation

143 Ibid at para 18.

144 Ibid at para 16.

145 Ibid at para 35.

146 Ibid at para 40.

147 Criminal Code, supra note 19, s 672.62.

148 Ibid, s 672.82(1); See also Michael Davies et al, supra note 19 at 257.

$149 A A$, ORB File No 6369 [AA, ORB].

150 Criminal Code, supra note 19, s 672.62.

151 AA, ORB, supra note 149.

152 Ibid. 
to Mr. M.I.'s early hearing request. ${ }^{153}$ M.I. requested an Early Review Hearing on the basis that COVID19 in the institution changed the risk / liberty analysis and therefore warranted a review of his Disposition. The ORB dismissed this argument instead writing that: "unless there is evidence that the hospital is not acting according to appropriate protocols, there is no basis for holding a hearing." 154 Over time and repeated efforts by NCR accused to get an early review hearing to seek a discharge from hospital, it became clear that no COVID-19 arguments, particularly relating to the risk of inpatients contracting COVID-19 in psychiatric facilities, would persuade the Board to grant the accused a hearing. The Board clearly found COVID-19 irrelevant to the Board's consideration of whether it should hold an Early Review Hearing. It doesn't help that there are no statutory criteria to guide the Board in making this decision, nor has the Board promulgated a practice directive or set out any guiding principles in its Rules of Practice. ${ }^{155}$ The Board's discretion is broad. It has, however, consistently chosen to exercise it narrowly, refusing accused persons access to the tribunal's hearing process to determine whether they may be safely discharged during a time when a deadly virus outbreak was on the rise within the institutions that detain them.

\section{Summary}

These cases demonstrate that NCR accused under the Review Board's jurisdiction are scared, increasingly vulnerable and concerned about the risks of COVID-19. A number of these individuals were close to being absolutely or conditionally discharged, but their "discharge plan" was halted due to COVID19. ${ }^{156}$ These individuals have had their liberty restricted and some remain in facilities infested with COVID-19. Many of them have pre-existing health conditions that put them at greater risk of contracting the virus and dying. Despite affected NCR accused persons' best efforts to raise these concerns with the Board when requesting Early Hearings to review Detention Disposition Orders, to date the Board has not been receptive to these arguments. This amounts to a significant barrier to access to justice during COVID19 , further increasing the liberty, health and safety risks to this vulnerable community.

\section{Consent and Capacity Board Decisions}

Between March and November 2020, we could identify only two reported decisions where the CCB considered substantive arguments in relation to the risks associated with COVID-19 within an institutional setting as the basis for seeking discharge of involuntarily detained individuals. ${ }^{157}$ The CCB may have considered COVID-19 related arguments in other cases; however, written reasons for CCB decisions are only issued if requested. ${ }^{158}$

In $B D(R e),{ }^{159}$ B.D.'s parents applied to have her involuntary status reviewed. They submitted that even if the Board found that the criteria for involuntary committal were met, the Board ought to exercise its discretion under s. 41(2) of the MHA to rescind BD's involuntary status. Section 41(2) of the MHA states that the "Board by order may confirm the patient's status as an involuntary patient if the Board determines that the prerequisites set out in this Act for admission as an involuntary patient were met at the

\footnotetext{
153 MI, ORB File No 2558.

154 Ibid.

155 ORB, "Rules", supra note 58.

156 MI, ORB, supra note 153; Williams, supra note 140.

$157 B D(R e), 2020$ CanLII 32317 (ON CCB) [BD]; TM, supra note 78.

158 HCCA, supra note 30.

$159 B D$, supra note 157.
} 
time of the hearing of the application". ${ }^{160}$ This is different than the language used in section 41(3), which mandates that the "Board shall rescind the certificate if the Board determines that the prerequisites set out in this Act for admission as an involuntary patient were not met at the time of the hearing of the application". ${ }^{161}$ The "permissive language" in s.41(2), contrasted with the "mandatory language" of s.41(3), "have led to the view that the Board has some discretion to rescind a certificate even where the prerequisites for involuntary detention are met". ${ }^{162}$ This is the relief BD's parents sought, citing the "ongoing risk in hospital due to the extraordinary circumstances of the COVID-19 pandemic.". ${ }^{163}$

The Board in BD acknowledged that the "COVID-19 pandemic may be a situation where it would be appropriate for the Board to exercise its discretion" ${ }^{164}$ but refused to do so in this case. At the time of the hearing, BD was on a "Leave of Absence (LOA)": 165 while she was still technically a "patient" on a Form of Renewal of a Certificate of Involuntary Admission, she lived with her parents, subject to certain conditions. The Board found that BD "was no longer in the hospital and exposed to potential risk of contracting COVID-19." "66 The Board went on to reflect on the evidence that may be required for the Board to exercise its discretion to rescind an involuntary admission due to the pandemic:

Further, while the COVID-19 pandemic may be a situation where it would be appropriate for the Board to exercise its discretion, the panel was of the view that specific evidence of risk at a particular psychiatric facility, and to a particular patient, would be required. While the Board could take judicial notice of the COVID-19 pandemic, a blanket statement about its effect in detention units would likely not be sufficient to exercise a discretion that is to be used cautiously and in "gregious" situations." 167

The panel also noted that prisons and other "places of detention"...were not the same as a psychiatric unit in a hospital. There were also different statutory tests and considerations to be applied in the criminal context that may not be as applicable in the mental health context. ${ }^{168}$

There was considerably less analysis given to similar arguments made in $T M(R e) .{ }^{169}$ T.M. was involuntarily detained on a unit with a COVID-19 outbreak. TM had tested positive for COVID-19 while detained on the unit. In its submissions, TM's counsel referred to a bail review case (R. v. J.S.), ${ }^{170}$ as authority. Justice Copeland granted bail in J.S., noting that the "greatly elevated risk posed to detained inmates from the coronavirus, as compared to being at home on house arrest is a factor that must be considered" 171 on a bail review, and that "the risks to health from [the] virus in a confined space with many people, like a jail, are significantly higher than if a defendant were able to self-isolate at home." 172 The CCB distinguished J.S. noting that 1) TM already tested positive for COVID-19 and there was a

160 Mental Health Act, supra note 31, s 41(2), (emphasis added).

161 Mental Health Act, supra note 31, s. 41(3) (emphasis added); BD, supra note 158 at 17.

162 BD, ibid.

163 Ibid.

164 Ibid at 19.

165 Mental Health Act, supra note 31, s 27(1); BD, supra note 157 at 17.

166 BD, supra note 157 at 19.

167 Ibid.

168 Ibid at 20.

169 TM, supra note 78.

170 JS, supra note 17.

171 Ibid at para 18.

172 Ibid at para 19. 
"greater risk to others if TM was discharged from hospital"; 173 2) TM did not have suitable housing; and 3) there was evidence that TM was "not able to follow even basic precautions to prevent others from potentially being infected with the virus." 174 The Board did not consider that TM contracted the virus during a COVID-19 outbreak on the unit where she was involuntarily detained. TM asked the panel to exercise its discretion under s.41(2) to rescind her involuntary admission. The Board provided no analysis of their decision but "chose not to do so". 175

The CCB's reluctance to rescind a patient's involuntary status due to the presence of COVID-19 in the hospital is sharply contrasted with their apparent willingness to accept the presence of COVID-19 in the community to confirm the applicant's involuntary status. In N.H. ${ }^{176}$ the panel found that the evidence "supported the likelihood of serious physical impairment of N.H. as a result of her belief that the COVID19 pandemic was a hoax, and she was therefore not keeping physical distance." ${ }^{177}$ They found that N.H. would be exposed to significant risk by not following COVID-19 precautions, which was likely to cause her serious physical impairment if she was not in hospital. The panel found that this could result in consequences to $\mathrm{NH}$ and possibly to others, and that the risk was greater since N.H. lived in the shelter system. Partly on that basis, the Board confirmed N.H.'s involuntary status. There are a number of similar rulings released by the Board, in which the applicant's involuntary status was confirmed at least partly on the basis of COVID-19 concerns. ${ }^{178}$

Lastly, it appears that the CCB in some cases has considered COVID-19 as a mitigating factor to justify delays in providing rights advice. In $J M^{179}$, the applicant had not received "prompt" rights advice after being found incapable to make treatment decisions, as required by Regulation 15(2) of the MHA. ${ }^{180}$ The Board accepted that "there was a delay in providing prompt rights advice" ${ }^{181}$ however, the panel also found that "due to the COVID-19 health crisis, significant strain had been placed on the health care system and its limited resources." 182 The panel ultimately found that "there were sufficient extenuating circumstances that justified the delay of rights advice". ${ }^{183}$

\section{V1I. CONCLUSION}

People with mental health and addiction issues are disproportionately affected by COVID-19 given the elevated risk of contracting COVID-19 within psychiatric facilities. The impact of the pandemic on this extraordinarily vulnerable population includes the potential for large outbreaks and multiple deaths. There is also the increased risk of serious psychological harm, exacerbating pre-existing mental health and substance use issues and in turn elevating their risk to themselves and/or others. ${ }^{184}$

TM, supra note 78 at 5.

Ibid at 6.

Ibid.

$176 \mathrm{NH}(\mathrm{Re}), 2020 \mathrm{CanLII} 34747$ (ON CCB) at 20.

177 Ibid at $19-20$.

178 See $L G$ (Re), 2020 CanLII 33296 (ON CCB); $M G$ (Re), 2020 CanLII 33228 (ON CCB); VL (Re), 2020 CanLII 33305 (ON CCB); $A T$ (Re), 2020 CanLII 33214 (ON CCB).

$179 J M(R e), 2020$ CanLII 34250 (ON CCB) [JM].

180 Mental Health Act, General, RRO 1990, Reg 741, Regulation 15(2), [emphasis added]

$181 J M$, supra note 179 at para 18.

182 Ibid.

183 Ibid; A similar ruling was issued by the Board in PM (Re), 2020 CanLII 34765 (ON CCB).

184 See sources at supra note 2. 
Given the evolving nature of COVID-19, our analysis reveals an array of litigation experiences before the CCB and ORB. Drawing from multiple sources including our own experience as front-line lawyers and advocates, we examined the pros and cons of the CCB's and ORB's initial and ongoing responses to COVID-19 in relation to various procedural, discretionary and systemic barriers to access to justice.

In Part I, we considered how the CCB's and ORB's responses to COVID-19 relate to procedural barriers for individuals with mental health and addictions issues appearing before them. We found that the CCB's preparedness and rapid transition to electronic hearings via teleconference was commendable. Their ongoing regular consultation with stake-holders during COVID-19 also benefits patient applicants who come before the Board. On the other hand, our analysis revealed that NCR accused under the ORB's jurisdiction were initially deprived of access to the tribunal altogether in the wake of COVID-19 and subsequently experienced some procedural barriers to access to justice as a result of technological and logistical issues. We recommend the ORB engage in broad stake-holder consultation going forward to facilitate streamlining its ongoing response to the global pandemic.

In Part V, we briefly examined how appeals taken from both tribunals have been handled throughout COVID-19 to date. Once again, the substantial benefit of ongoing stake-holder consultation was evident in the approach Ontario's Court of Appeal has taken to ensure that time-sensitive appeals to that Court from the ORB are processed and heard efficiently to ensure access to justice for vulnerable appellants. By contrast, the Superior Courts appear to have discounted, at least initially, the generalized urgency and significance of appeals taken from the CCB to that Court as those matters affect liberty and autonomy interests of vulnerable individuals. Greater stakeholder consultation in relation to CCB appeals before the Superior Court is recommended.

In Part VI, we examined recent CCB and ORB cases during COVID-19 where deprivations of liberty interests and substantive equality have occurred, and access to justice for people with mental health and addictions issues has been denied, suspended or impaired. Our analysis found that both tribunals responded similarly to arguments, advanced on behalf of the patient/client or accused person, regarding COVID-19. They struggled to appreciate that the psychiatric hospital itself now poses a public health risk to the detained inpatient given the high transmission risks inside. Instead of depopulating psychiatric hospitals, the ORB and CCB appear to have a preference in favour of keeping individuals detained for their "protection" and in the interests of "public safety." This approach is rooted in what we argue reflects an outdated and troubling historical beneficence, the State's paternalistic parens patriae powers. ${ }^{185}$ The analysis exposes emerging access to justice issues, which adversely affect and could result in serious violations of the Charter-protected rights of involuntarily detained psychiatric patients.

We conclude that there are many opportunities to learn from both mental health tribunals' procedural and substantive responses to COVID-19. We acknowledge the leadership of the tribunals and their ability to rapidly develop new protocols during the global pandemic. Our analysis suggests that mental health tribunals should use legal safeguards, administrative discretion, inclusion and empathy to proactively address the risks of COVID-19. They must take care to meaningfully consider the lived experience of people with mental health and addictions issues involuntarily detained in psychiatric facilities during the pandemic. The onus is on us as lawyers, academics and advocates to educate ourselves and advocate, through every available means, for implementation of measures that could prevent outbreaks and death, improve health care practices, and increase access to justice.

185 E (Mrs), supra note 6. 